DOE/NV/26383-23

LMS/RUL/S08087

\title{
Screening Assessment of \\ Potential Human-Health Risk from \\ Future Natural-Gas Drilling Near \\ Project Rulison in Western Colorado
}

Jeffrey I. Daniels

Jenny B. Chapman

January 2012

Publication No. 45237

Prepared by

Division of Hydrologic Sciences, Las Vegas, NV

Desert Research Institute, Nevada System of Higher Education

Prepared for

S. M. Stoller Corporation, Office of Legacy Management

U.S. Department of Energy, Grand Junction, Colorado 
Reference herein to any specific commercial product, process, or service by trade name, trademark, manufacturer, or otherwise, does not necessarily constitute or imply its endorsement, recommendation, or favoring by the United States Government or any agency thereof or its contractors or subcontractors.

Available for sale to the public from:

U.S. Department of Commerce

National Technical Information Service

5301 Shawnee Road

Alexandria, VA 22312

Phone: 800.553.6847

Fax: 703.605.6900

Email: orders@ntis.gov

Online ordering: http://www.osti.gov/ordering.htm

Available electronically at http://www.osti.gov/bridge

Available for a processing fee to the U.S. Department of Energy and its contractors, in paper, from:

U.S. Department of Energy

Office of Scientific and Technical Information

P.O. Box 62

Oak Ridge, TN 37831-0062

Phone: 865.576.8401

Fax: 865.576.5728

Email: reports@adonis.osti.gov 


\title{
Screening Assessment of Potential Human-Health Risk from Future Natural-Gas Drilling Near Project Rulison in Western Colorado
}

\author{
Jeffrey I. Daniels \\ Jenny B. Chapman
}

January 2012

Publication No. 45237

Prepared by

Division of Hydrologic Sciences, Las Vegas, NV

Desert Research Institute, Nevada System of Higher Education

Prepared for

S. M. Stoller Corporation, Office of Legacy Management

U.S. Department of Energy, Grand Junction, Colorado

Work performed for S.M. Stoller as part of their Contract DE-AC01-02GJ79491 for the U.S. Department of Energy Office of Legacy Management. Approved for public release; distribution is unlimited. 
THIS PAGE INTENTIONALLY LEFT BLANK 


\section{ACKNOWLEDGMENT}

The authors of this report express their sincerest gratitude to C. Cooper and C. Russell of Desert Research Institute (DRI) in Reno and Las Vegas, NV, and to the Stoller and U.S. Department of Energy personnel at the Office of Legacy Management (LM) in Grand Junction, $\mathrm{CO}$, for their participation and contributions to valuable discussions focusing on modeling, chemistry, and engineering practice. We also extend our thanks to Ms. Camille Phillips at DRI in Las Vegas, NV, for her clerical assistance, and to Ms. Debi Noack at DRI in Reno, NV, for her support in preparing this document for publication. 
THIS PAGE INTENTIONALLY LEFT BLANK 


\section{CONTENTS}

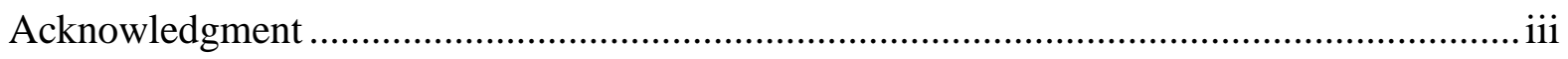

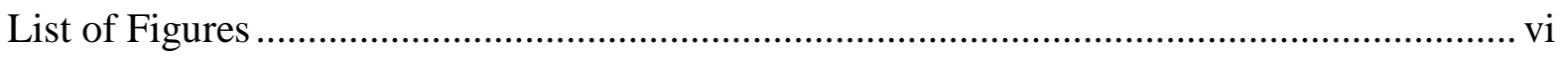

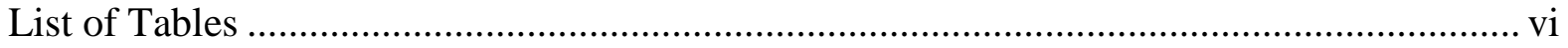

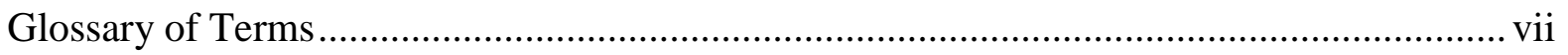

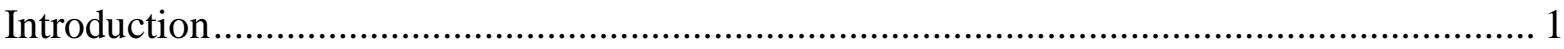

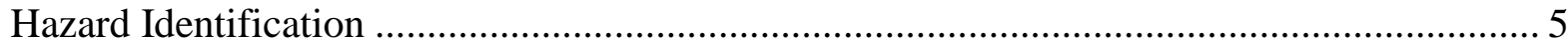

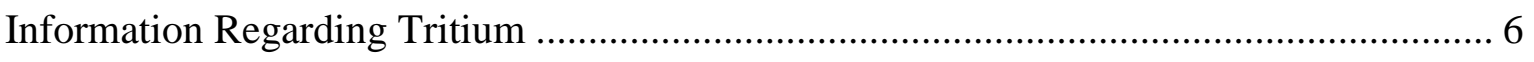

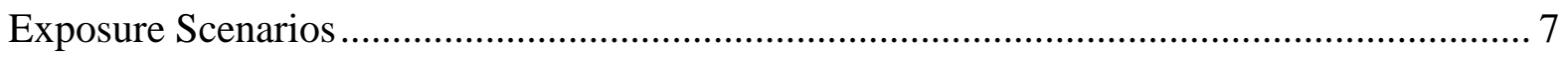

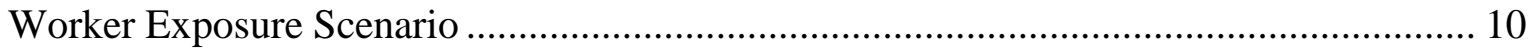

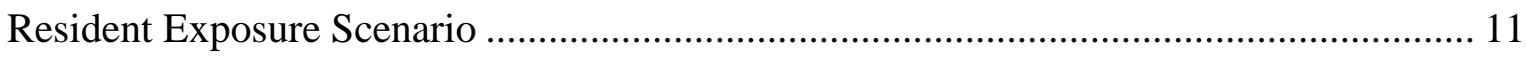

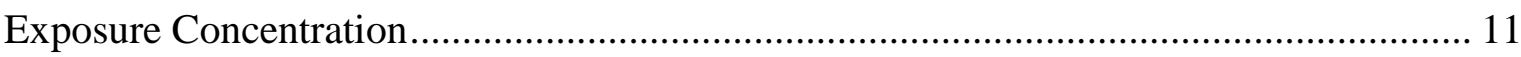

Exposure Concentration for Screening Risk Calculation ....................................... 11

Exposure Concentration for Consequence Assessment .......................................... 13

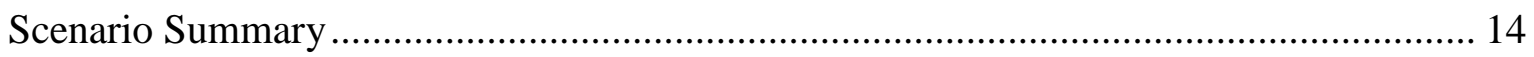

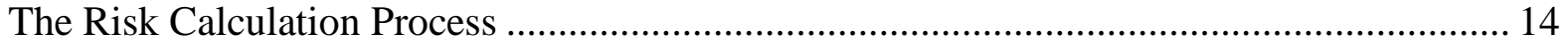

Screening Estimates of Human-Health Risk................................................................ 16

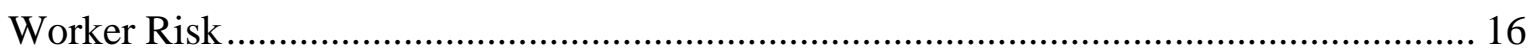

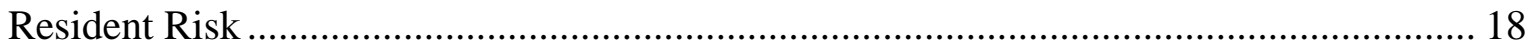

Sensitivity of Risk Assessment Results to Parameter Uncertainty ................................ 19

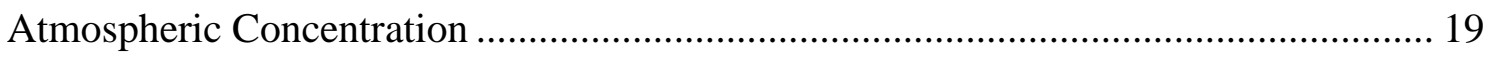

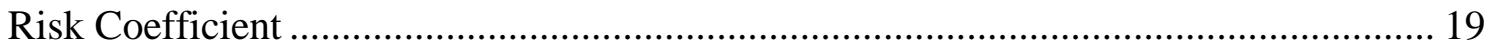

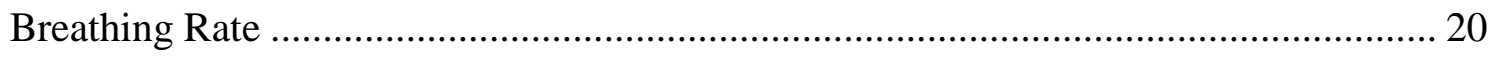

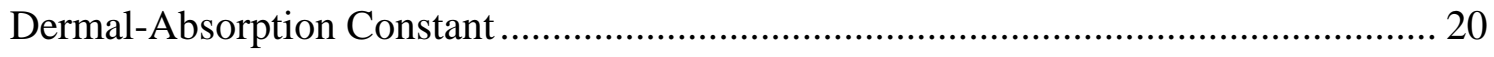

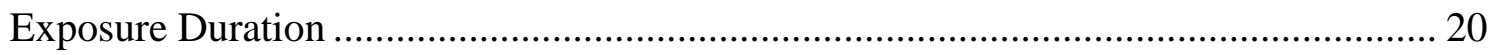

Effect of Compounding Upper Bounds of Parameter Uncertainties ........................... 22

Consequence Assessment for Human-Health Risk....................................................... 22

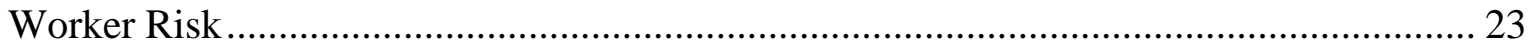

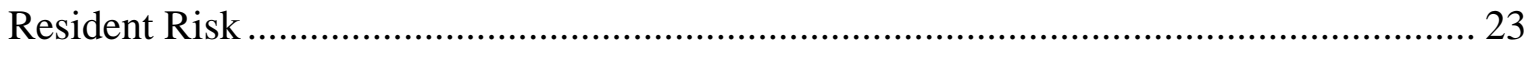

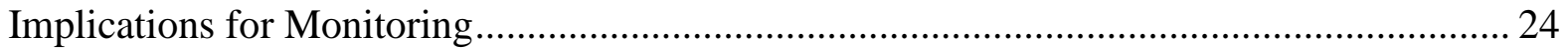

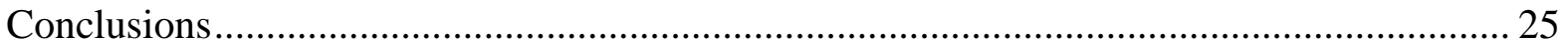


Appendix A: Converting a Tritium Concentration in Produced Water $\left(\mathrm{HTO}_{\text {liquid }}\right)$ to a Corresponding Concentration of Tritium Vapor $\left(\mathrm{HTO}_{v}\right)$ and Vice Versa. 30

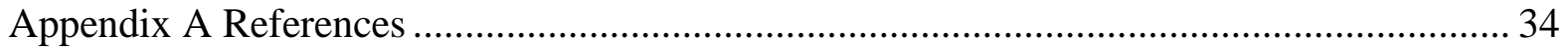

Appendix B: Derivation of Age-Specific Health Risk ................................................. 35

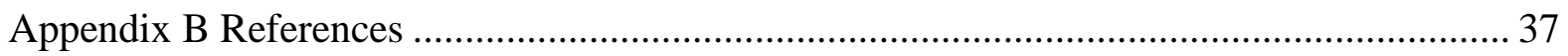

\section{LIST OF FIGURES}

1. Location map for the Piceance Basin in northwestern Colorado. ................................. 2

2. Cross section view of the Rulison nuclear test, denoted by the black line extending from surface ground zero to the detonation depth.............................................. 3

3. Conceptual exposure scenarios to $\mathrm{HTO}_{v}$ from the Rulison subsurface for a worker

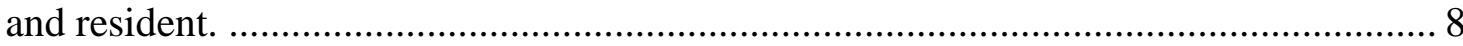

4. Sketch map of the Rulison nuclear test location, shown as the red circle in Lot $11 \ldots . .21$

\section{LIST OF TABLES}

1. Description of pertinent characteristics of Project Rulison........................................ 4

2. Estimated excess lifetime cancer morbidity risk (R/lifetime) for adult workers and nearby residents (adult and child), from inhalation and dermal exposure to $\mathrm{HTO}_{v}$ at (a) an air concentration derived from the detection limit used in the current monitoring program for tritium in liquid water $(400 \mathrm{pCi} / \mathrm{L})$, and (b) a hypothetical concentration of $\mathrm{HTO}_{v}$ in air represented by the maximum reported atmospheric concentration of $\mathrm{HTO}_{v}$ during flaring operations of gas produced directly from the Project Rulison nuclear chimney on October 28, 1970, from a sampling point within a few hundred feet of the flare stack

A-1. Concentrations of tritium vapor $\left(\mathrm{HTO}_{v}\right)$ in $\mathrm{pCi} / \mathrm{m}^{3}$ for summer and winter atmospheric conditions of temperature, relative humidity, absolute humidity, and water density near Project Rulison, converted from a tritium concentration in produced water $\left(\mathrm{HTO}_{\text {liquid }}\right)$ equal to $400 \mathrm{pCi} / \mathrm{L}$.

A-2. Comparison of product-water concentrations of tritium $\left(\mathrm{HTO}_{\text {liquid }}\right)$ corresponding to summer and winter atmospheric conditions of temperature, relative humidity, absolute humidity, and water density near Project Rulison, and associated with different concentrations of atmospheric $\mathrm{HTO}_{v}$, which were derived using realistic upper-limit exposure parameters for worker and resident, total lifetime exposure durations of $30 \mathrm{~d}$ and a de minimis excess cancer morbidity risk equal to $1 \times 10^{-6} \ldots 33$

B-1. Derivation of age-specific (0 to $70 \mathrm{y}$ ) tritium inhalation morbidity risk coefficients per unit activity $(\mathrm{R} / \mathrm{pCi})$ and determination of age-specific maximum lifetime excess cancer morbidity risk for risk and consequence assessment scenarios 


\section{GLOSSARY OF TERMS}

amsl

ATSDR

bgs

$\boldsymbol{B} \boldsymbol{R}_{\boldsymbol{i}}$

$\mathrm{CH}_{3} \mathbf{T}_{\text {gas }}$

$\mathrm{C}_{\mathrm{HTO}_{v}-\mathrm{air}}$

CCR

CDPHE

CFR

COGCC

DAC

derm

${ }^{3} \mathbf{H}$ and $\mathbf{T}$

$\mathrm{H}_{2} \mathrm{O}$ and HTO

HEAST

HTO $_{\text {liquid }}$

HTO $_{V}$

inh

$\mathbf{k}_{\text {derm }}$

LM

$\operatorname{MBYR} C_{H T o_{v}}^{\text {inh }}$

MDC
Above mean sea level (elevation)

Agency for Toxic Substances \& Disease Registry (United States)

Below ground surface (i.e., at depth)

Breathing rate for [exposed] individual $(i)$ for either occupational ( $i=$ worker $)$ or public $(i=$ resident $)$ exposure

Tritiated $\left(\mathrm{T}={ }^{3} \mathrm{H}\right)$ methane (natural) gas

Concentration of tritiated $\left(\mathrm{T}={ }^{3} \mathrm{H}\right)$ water vapor in air (expressed as activity per unit volume)

Colorado Code of Regulations

Colorado Department of Public Health and Environment

Code of Federal Regulations (CFR)

Colorado Oil \& Gas Conservation Commission

Derived air concentration [equating to the quotient of the acceptable limit of intake and the exposure (by inhalation) -to-dose conversion factor for $\mathrm{HTO}_{v}$ ]

Dermal exposure pathway

Tritium isotope $\left({ }^{3} \mathrm{H}\right.$, also expressed as $\left.\mathrm{T}\right)$ of hydrogen [half-life $\left(\mathrm{t}_{1 / 2}\right)$ equal to approximately $\left.12.3 \mathrm{y}\right]$

Water; and tritiated water $\left({ }^{3} \mathrm{H}^{3} \mathrm{HO}\right.$ or $\mathrm{H}^{3} \mathrm{HO}$; expressed as HTO)

Health Effects Assessment Summary Table(s) prepared by the United States Environmental Protection Agency (USEPA)

Tritated $\left({ }^{3} \mathrm{H}\right)$ liquid water

Tritiated $\left({ }^{3} \mathrm{H}\right)$ water vapor $(v)$

Inhalation exposure pathway

Dermal-absorption constant by which breathing rate (BR) is multiplied to account for absorption of $\mathrm{HTO}_{\mathrm{v}}$ through exposed skin

United States Department of Energy Office of Legacy

Management

Morbidity $(\mathrm{MBY}=$ fatal and nonfatal) cancer risk coefficient $(R C)$ for inhalation (inh) exposure to $\mathrm{HTO}_{v}$ [expressed as lifetime excess morbidity cancer risk $(\mathrm{R})$ per unit activity]

Minimum detectable concentration 
PHA

res

SAP

SGZ

$\mathbf{t}_{1 / 2}$

$T E_{i}$

US

USAEC

USDOE

USEPA

USNRC

wkr
Public Health Assessment (performed by ATSDR for accidental tritium released from the Lawrence Livermore National Laboratory between 1965 and 1970)

Lifetime excess morbidity ( $M B Y$; fatal and nonfatal) cancer risk for an individual (i) exposed by inhalation and dermal contact to tritiated water vapor $\left(\mathrm{HTO}_{v}\right)$

resident (applicable to public health risk)

Sampling and Analysis Plan (for Project Rulison)

Surface ground zero (above working point for Project Rulison)

half-life of radionuclide

Total exposure over lifetime [d/lifetime] for individual $(i)$ for either occupational $(i=$ worker $)$ or public $(i=$ resident $)$ exposure United States (also U.S.)

United States Atomic Energy Commission

United States Department of Energy

United States Environmental Protection Agency

United States Nuclear Regulatory Commission

worker (applicable to occupational health risk) 


\section{INTRODUCTION}

The Project Rulison underground nuclear test was conducted in 1969 at a depth of $8,400 \mathrm{ft}$ in the Williams Fork Formation of the Piceance Basin, west-central Colorado (Figure 1). The U.S. Department of Energy Office of Legacy Management (LM) is the steward of the site. Their management is guided by data collected from past site investigations and current monitoring, and by the results of calculations of expected behavior of contaminants remaining in the deep subsurface.

The purpose of this screening risk assessment is to evaluate possible health risks from current and future exposure to Rulison contaminants so the information can be factored into LM's stewardship decisions. For example, these risk assessment results can inform decisions regarding institutional controls at the site and appropriate monitoring of nearby natural-gas extraction activities. Specifically, the screening risk analysis can provide guidance for setting appropriate action levels for contaminant monitoring to ensure protection of human health.

Human health and the environment are protected from radionuclides remaining in the deep subsurface from the Rulison test by three mechanisms: 1) administrative directives and restrictions (institutional controls), 2) the geologic properties of the gas-bearing formation, and 3) monitoring.

Institutional controls restrict drilling below 6,000 ft in Lot 11 (where the nuclear test occurred), and restrict the removal of any material from within Lot 11 at those depths (Figure 2). As a result, contaminants would need to migrate through the subsurface for them to enter a gas well and reach the accessible environment.

The Williams Fork Formation is characterized by very low permeability sandstone lenses isolated by surrounding shale. Commercial production of natural gas requires hydraulic fracturing of these sandstones. Natural-gas production experience in the area shows that these hydrofractured wells can be located on 10-acre spacing without experiencing communication between wells (Williams Production Company, 2006).

LM and the Colorado Oil and Gas Conservation Commission (COGCC) have developed and implemented monitoring plans for natural gas wells near Project Rulison. The plans call for sampling of natural gas and produced water (i.e., water co-mingled with the natural gas stream) for wells close to the site. To date, no Rulison-related contaminants have been detected.

Geologic data from nearby production wells, current and historical monitoring data, historical nuclear-test information, and transport modeling calculations (Cooper et al., 2007, 2009, and 2010; Ye et al., 2009) indicate that contamination from the Rulison nuclear test is confined to the 40-acre lot (Lot 11) surrounding the test and will not migrate beyond the lot boundary in the future (see "Plan View" in Fig. 2). Nonetheless, LM has decided to 


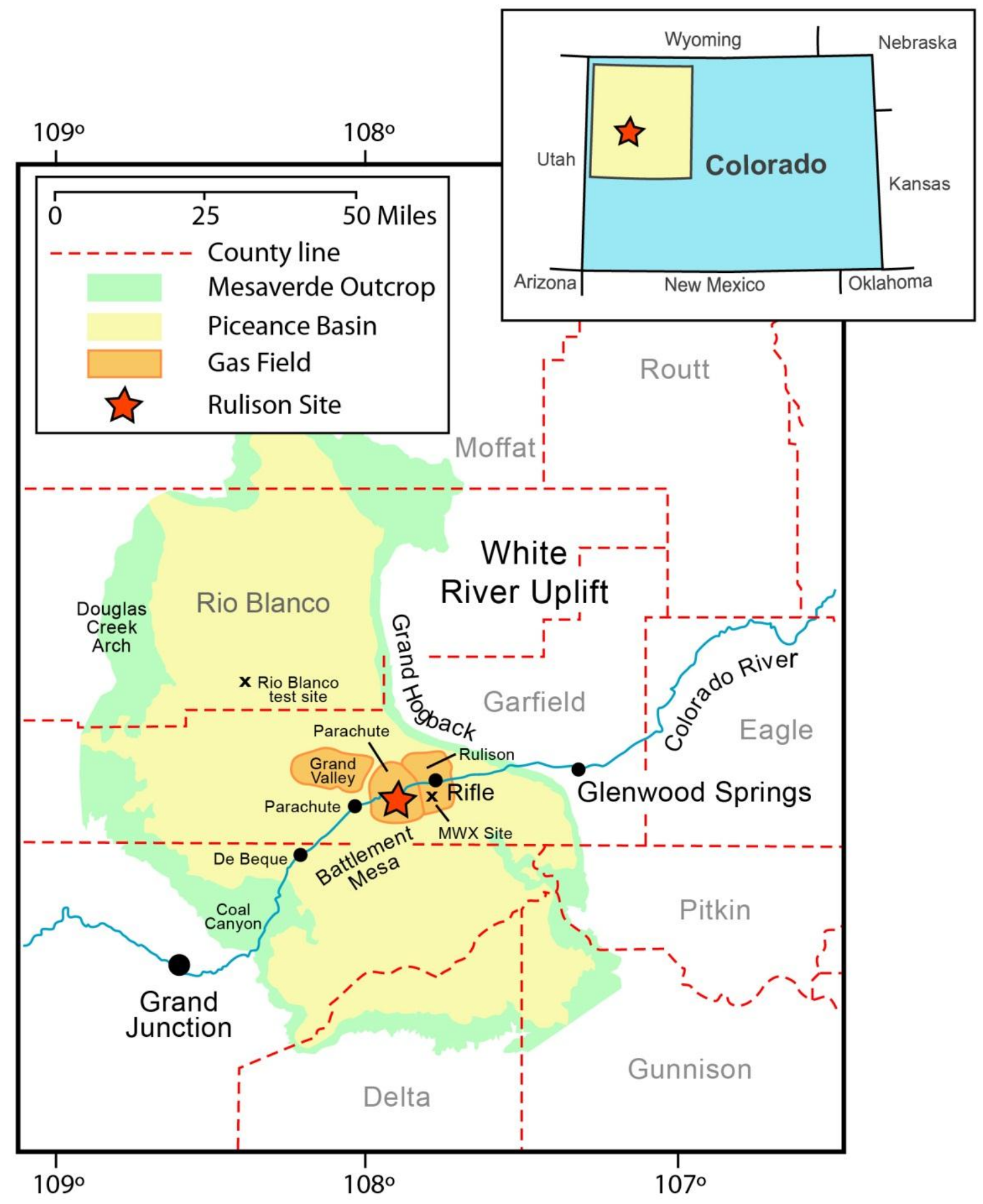

Figure 1. Location map for the Piceance Basin in northwestern Colorado. The Rulison nuclear test site is located in the Battlement Mesa area. 


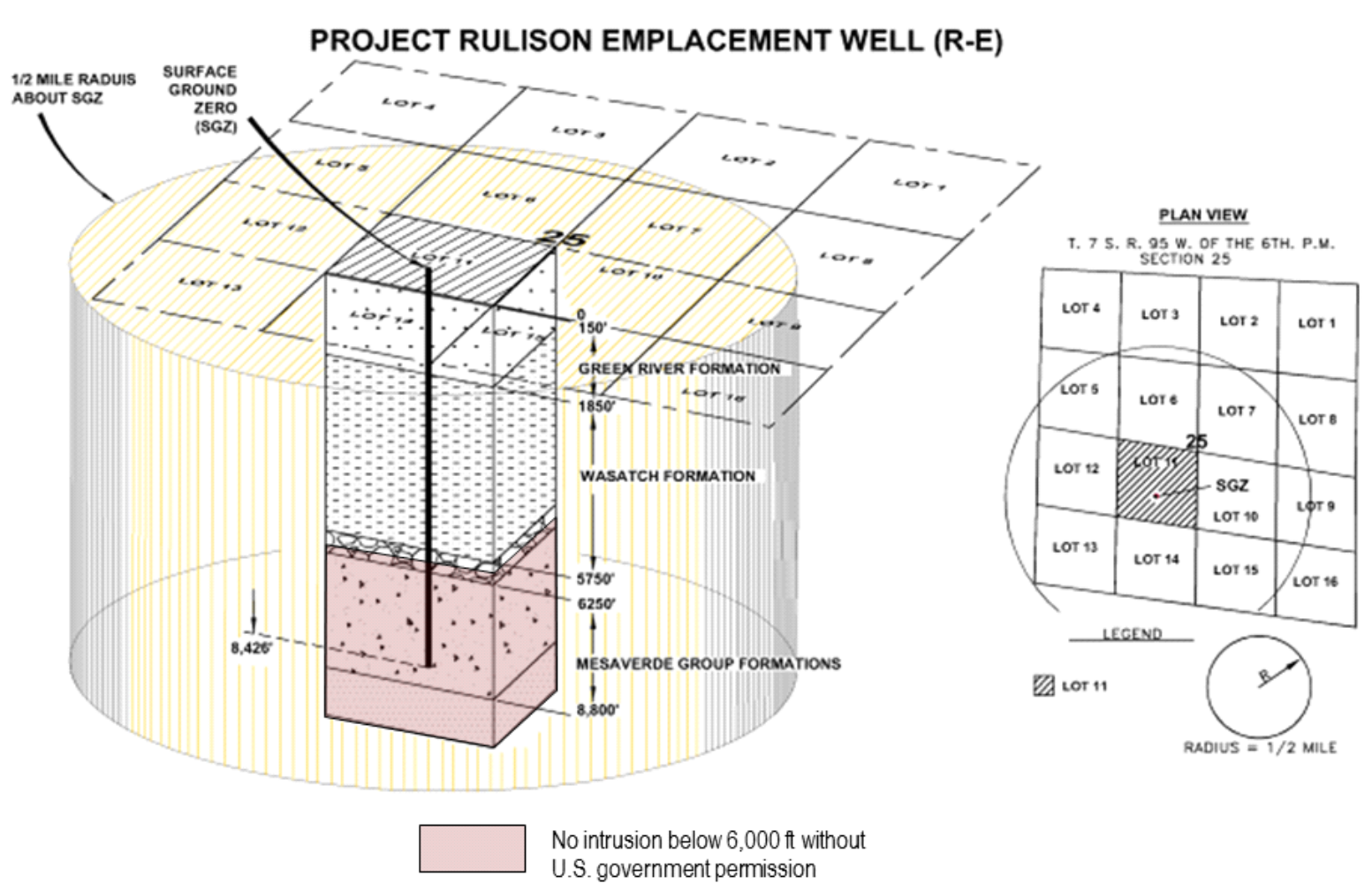

Figure 2. Cross section view of the Rulison nuclear test, denoted by the black line extending from surface ground zero to the detonation depth. The institutional controls restrict drilling in Lot 11 below a depth of 6,000 ft. From a presentation by the USDOE to COGCC on 7-15-09.

determine the potential human health risk in the event that contaminant migration does occur. This will allow LM to consider the following sources of information while managing the site for protection of the public and environment: predictions of contaminant behavior, potential human health consequences in the event the predictions are incorrect, and monitoring data from nearby gas wells.

This screening assessment of potential human-health risk does not attempt to estimate the probability of exposure. The flow and transport modeling indicate that the geologic properties of the Williams Fork Formation, existing site management controls, and gas-well development practices will prevent migration of Project Rulison radionuclides beyond Lot 11 to future nearby gas wells, and then to the accessible environment. Based on that information, a classic risk assessment considering probability of exposure and consequence of exposure would result in no health risk because there is no probability of exposure. In order to provide decision makers with information about possible human health impacts, two 
alternate approaches are used, both of which simply assume exposure occurs. One approach relies on current monitoring data to assign an exposure concentration and evaluate current potential health risk. The other approach uses historic monitoring data from the time of the nuclear test to assess the consequences in the event unexpected contaminant migration occurs in the future. Several recent publications have summarized historic information about the Rulison nuclear test and current activities in the area. The reader is directed to the "Rulison Path Forward" (USDOE, 2010a) and the "Rulison Monitoring Plan" (USDOE, 2010b) for concise descriptions of the site conditions, and to Cooper et al. (2007) and USAEC (1973) for more detailed discussions. These documents can be obtained from the LM internet site at http://www.lm.doe.gov/Rulison/Documents.aspx. The pertinent characteristics of the nuclear test are summarized in Table 1.

Table 1. Description of pertinent characteristics of Project Rulison ${ }^{\mathrm{a}}$

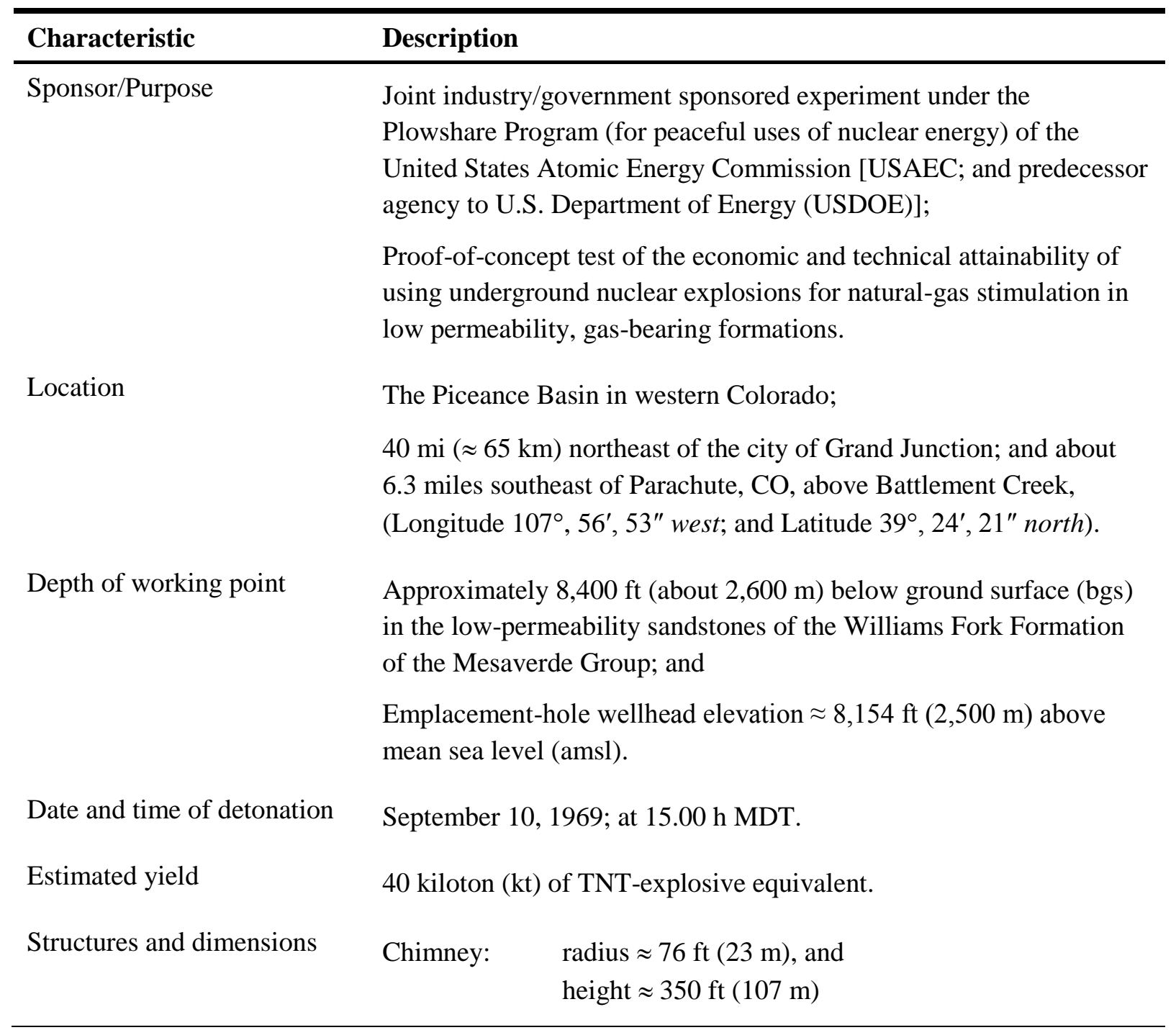

${ }^{a}$ Compiled from data appearing in Nork and Fenske (1970); Fort et al. (1972); and USDOE (2010b). 
The risk analysis contains the following sections. First the selection of tritium in water vapor as the hazard (constituent of concern) is discussed. Next, exposure scenarios are described that analyze pathways for Project Rulison tritium to reach humans. There are two basic scenarios; one for a worker on a gas well, and one for a resident, including both an adult and a child. The risk calculation process is presented, explaining the factors that are included in that calculation. The current assessment of potential human health risk is then presented, relying on monitoring data collected at gas production wells near the Rulison site. Next, the uncertainties in the risk calculation are examined. The consequence assessment is then presented, using historic monitoring data from the time period when natural gas was flared to the atmosphere directly from the nuclear chimney. Implications of the risk results for environmental monitoring are explored. The conclusion summarizes the findings and puts them in context with health standards and regulations.

\section{HAZARD IDENTIFICATION}

This assessment is specific to hazards related to contaminant transport from the Project Rulison underground nuclear test. Significant health and safety hazards can be present in any exploration and production of natural gas from geologic reservoirs, but these are not considered here. Instead, the analysis focuses on determining what hazards are present as a result of radionuclides remaining in the Project Rulison nuclear chimney. Detailed descriptions of the underground nuclear test, its radionuclide products, and their disposition in the subsurface can be found in the "Project Manager's Report" (USAEC, 1973), with a more recent summary and analysis in Cooper et al. (2007). The following information is from these sources and the references they cite.

The vast majority of radionuclides produced by the nuclear test remain in the rubblefilled nuclear chimney created by the collapse of rock into the cavity void resulting from the nuclear detonation (this "chimney" at Rulison is estimated to be about $350 \mathrm{ft}$ high and $150 \mathrm{ft}$ wide), and most of these are entrained in solidified nuclear melt glass. Though some radionuclides may be present dissolved in liquid water, or have the potential to dissolve in water $\left(\mathrm{H}_{2} \mathrm{O}\right)$, the very low permeability, partially gas-saturated environment of the lower Williams Fork Formation prevents effective liquid-phase movement. As a result, radionuclides that have a gas-phase are the only ones capable of migration from the nuclear chimney in timeframes of tens to hundreds of years. Gas-phase radionuclides to consider at

Rulison include tritium $\left({ }^{3} \mathrm{H}\right.$ or T), Krypton-85 $\left({ }^{85} \mathrm{Kr}\right)$, and Carbon-14 $\left({ }^{14} \mathrm{C}\right)(\mathrm{Smith}, 1971)$.

There was extensive production testing and removal of radionuclide-contaminated gas shortly after the nuclear test. Monitoring data from the produced gas show that tritium is the only radionuclide remaining in significant quantities in the subsurface that has a gas phase, and the form of the tritium is as part of the water molecule. This means that tritium occurs in water vapor (mixed with the methane gas), and also in liquid water. 
Tritiated methane (natural) gas $\left(\mathrm{CH}_{3} \mathrm{~T}_{\text {gas }}\right)$ was essentially all removed during the production testing. Indeed, measurements show a rapid decline in radionuclide concentration during production testing, leading to the conclusion that "essentially all the original chimney gas components have been produced" and that gas produced toward the end of production testing from the chimney was uncontaminated formation gas (Smith, 1971). This pertains not

only to $\mathrm{CH}_{3} \mathrm{~T}$, but also to ${ }^{14} \mathrm{C}$ (as ${ }^{14} \mathrm{CO}_{2}$ or ${ }^{14} \mathrm{CH}_{4}$ ) and ${ }^{85} \mathrm{Kr}$. Consequently, natural gas is not a potential exposure pathway for remaining Rulison radionuclides. The reason that tritium remains a concern is that its presence in liquid water in the chimney prevented its complete removal during gas-production testing. Indeed, slightly less than a third of the tritium estimated to result from the Rulison experiment was removed during production testing (Smith, 1971; USAEC, 1972; Cooper et al., 2007). During the Rulison experiment, contaminated liquid water produced from the well and disposed by injecting into the flared gas stream contributed a larger total release of tritium than did the natural gas. On the last day of flaring, $9 \mathrm{Ci}$ of tritium was released, with only $0.08 \mathrm{Ci}$ originating in the natural gas (Anspaugh et al., 1971; USAEC, 1972).

As a result of the measured radionuclide concentrations in fluids removed from the nuclear chimney, and the measured characteristics of the Williams Fork Formation, the hazard identified is for exposure to tritiated water originating from the Rulison chimney. Migration of the tritiated water (HTO) through the Williams Fork Formation can only effectively occur in the vapor (gas phase) of water; however, the exchange of tritium between gas and liquid phases is rapid. This means that tritiated water vapor $\left(\mathrm{HTO}_{v}\right)$ that travels through the subsurface will equilibrate with liquid water $\left(\mathrm{HTO}_{\text {liquid }}\right)$ it contacts, such that tritiated water may be found in either phase. The subsequent analysis therefore considers possible exposure to tritiated water as a result of gas exploration and production near the Rulison test.

\section{Information Regarding Tritium}

Tritium is a radioactive isotope of hydrogen. The U.S. Environmental Protection Agency (USEPA) provides general information regarding tritium (USEPA, 2011), which is summarized here. Everyone is exposed to tiny amounts of tritium daily, much of it produced naturally. For example, tritium is produced in the upper atmosphere when cosmic rays strike nitrogen molecules. Tritium is also a product of nuclear weapons explosions and was introduced into the atmosphere by above-ground weapons testing, which occurred between 1945 and 1963. Consequently, the quantity of tritium introduced into the atmosphere from weapons testing peaked in 1963 and has been decreasing ever since.

Tritium can be a gas, and reacts with oxygen to form water. Most tritium in the environment is in the form of tritiated water, which easily disperses in the atmosphere, water bodies, soil, and rock. Therefore, people are exposed to tritium in the atmosphere and in the food chain. Tritium emits only a very low-energy beta particle as it decays to stable, nonradioactive helium. Tritium has a radioactive half-life of 12.3 years. 
Tritium primarily enters the body when people swallow tritiated water. However, people may also inhale tritium as a gas in the air, and absorb it through their skin. Once tritium enters the body, it disperses quickly and is uniformly distributed. Because most tritium is encountered as water, the majority entering the body will go into soft tissues and organs. The associated doses to these tissues from the beta emissions are generally uniform and dependent on water content of the tissue. A small fraction of tritium may also become organically bound. Nevertheless, most tritium is excreted through the urine within a month or so after ingestion, but that small fraction which is organically bound will remain in the body longer. As with all ionizing radiation, exposure to tritium increases the risk of developing cancer. However, because it emits very low energy radiation and leaves the body relatively quickly, for a given amount of activity ingested, tritium is one of the least dangerous radionuclides.

Standards have been established by the USEPA for the maximum amount of tritium that may be released by nuclear facilities, and that may be found in drinking water. Also, sites previously contaminated with tritium must meet USEPA's risk-based criteria for soil and ground water in order to be approved for public use. Based on these criteria, a cleaned-up site can be released for public use if the increased risk of developing cancer for an individual from exposure to tritium at the site is no more than a chance of 1-in-10,000 to 1-in-1,000,000 (USEPA, 2011).

\section{EXPOSURE SCENARIOS}

Assessing potential impacts to human health from drilling near the Rulison site requires determining the conditions of exposure. One challenge is that there is no current exposure, so these factors in the assessment must be inferred or assumed rather than directly measured. This entails an unavoidable level of subjectivity in selecting parameter values to implement a conceptual exposure scenario. The parameter values applied in this assessment are described below, but it is important to note from the outset that other scenarios may be equally valid. The objective in the selections made here is to realistically represent current practices in the gas industry while including reasonable conservatism (erring on the side of overestimating exposure). A later section examines uncertainty in the scenario parameters.

Two fundamental exposure scenarios are developed; one regarding a worker and another regarding adult and child residents (Figure 3). Each scenario must define what the person is exposed to (concentration and form) and for how long. The tritiated water is currently located in the deep subsurface of the Williams Fork Formation at a depth in excess of $8000 \mathrm{ft}$. The exposure scenarios thus rely on drilling and production of natural gas to provide a pathway for the tritium to reach land surface. Both scenarios begin with the assumption that a new well drilled adjacent to Lot 11 encounters HTO originating from the Rulison test. It is important to note here that $\mathrm{CH}_{3} \mathrm{~T}_{\text {gas }}$ is not considered because, as described previously, it was largely removed as a result of post-detonation production and flaring of gas in 1970 to 1971 . 


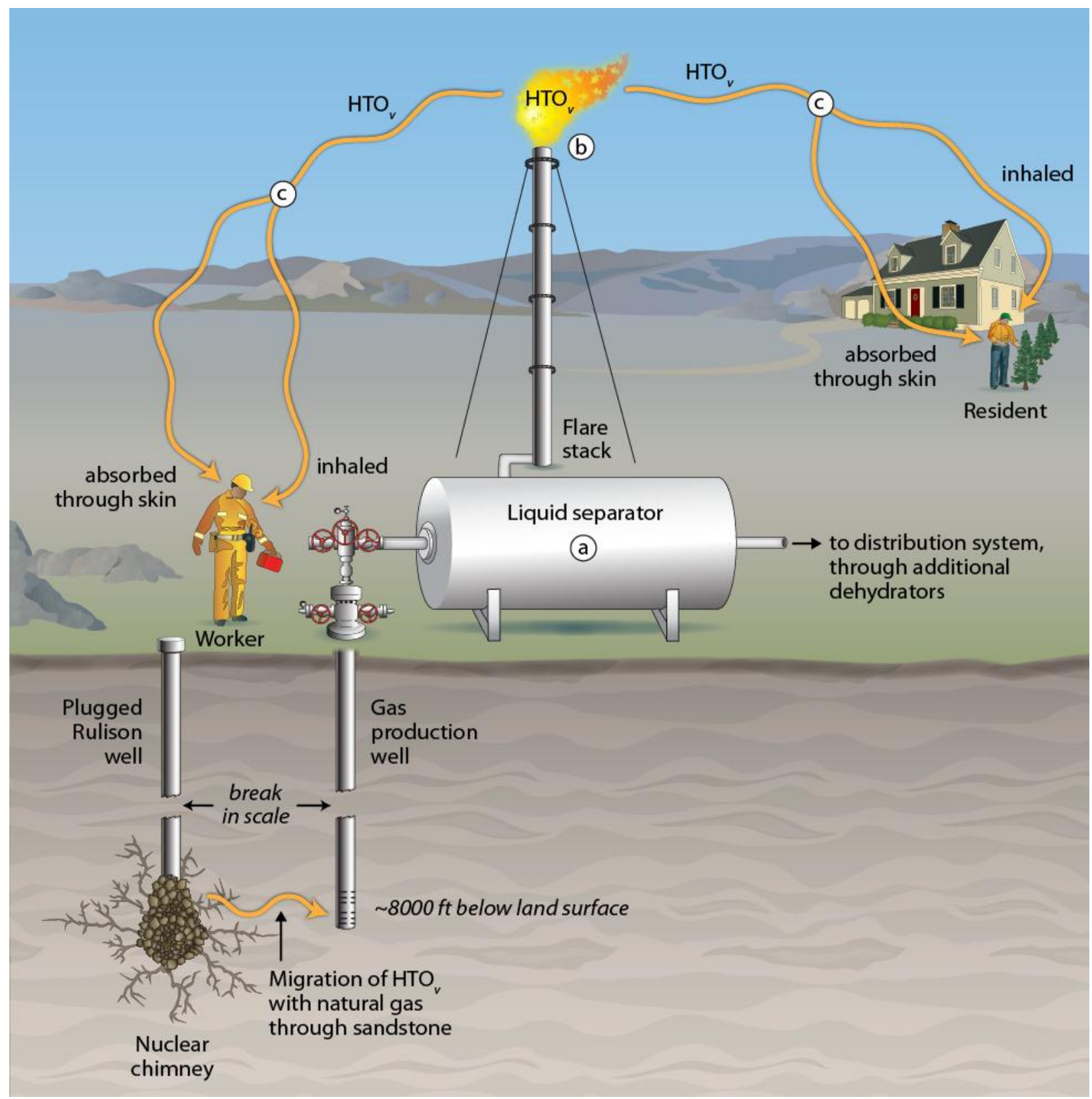

Figure 3. Conceptual exposure scenarios to $\mathrm{HTO}_{v}$ from the Rulison subsurface for a worker and resident. Point " $a$ " indicates the location where liquid water samples can be collected for monitoring. Point " $b$ " represents the flare stack, prior to combustion and release of gas and vapor to the environment. Point "c" is the atmosphere downwind of the flare stack, subject to the dispersing processes of wind, thermal mixing, etc. The mountain, human figures, and house illustrations are courtesy of the Integration and Application Network (ian.umces.edu/symbols/). 
This conceptual pathway is as follows:

1. A new well is drilled for the development of natural gas from the lower portion of the Williams Fork Formation;

2. The well is hydrofractured and, due to some unexpected coincidence of formation properties and hydrofracture engineering, a fracture connection is made with the Rulison nuclear chimney;

3. The well undergoes a development process to remove hydrofracturing fluids and optimize well performance. Some liquids removed in this process are captured in tanks on the surface (most of this liquid originated from injection during hydrofracturing). Natural gas, along with some entrained liquids, are typically combusted and discharged into the atmosphere as a consequence of flaring (burning) during the development process; and

4. The production phase of the well begins, with sealed piping systems moving gas from the wellhead and eventually to distribution systems. At several points along that pathway, beginning at the wellhead, there are dehydrating steps to remove water vapor (and other impurities) from the natural gas. These dehydrating processes will effectively remove tritiated water vapor from the natural gas during the industrial production process, preventing transfer of tritium to gas customers. There is also mixing with natural gas from many other locations that occurs along the way from wellhead to distribution pipeline.

The method of radioactive decay for tritium is by means of the release of a beta particle, which is a relatively low-energy emission with a range in air of about ten feet. Penetration of this beta particle is blocked effectively by materials such as plastics, clothing, or safety glasses. As a result, health concerns for exposure to tritium arise when there is a route that brings the tritium inside the body into proximity with internal organs, or externally into contact with unprotected skin and eyes. With the pathway described above, the primary opportunity for internal exposure is by means of inhalation during the flaring activity, when a person could inhale $\mathrm{HTO}_{v}$ released to the atmosphere with the natural gas.

Ingestion of $\mathrm{HTO}_{\text {liquid }}$ is not considered a viable pathway. The quality of produced liquid water is non-potable (due to high salinity, the presence of other hydrocarbons, and hydrofracturing compounds) and it is handled and disposed of per Colorado regulations. The same is true of liquid water condensed and removed from the natural-gas stream.

Given the pathway described above, both the worker and resident (adult and child) exposures are based on inhalation and dermal absorption by exposed skin. The dermal absorption is by virtue of absorption of $\mathrm{HTO}_{v}$ from the humid air surrounding the body. A 
worker could also experience occasional dermal absorption of $\mathrm{HTO}_{\text {liquid }}$ as a result of incidental splashes or similar incidents managing liquids during the industrial process.

\section{Worker Exposure Scenario}

Several types of workers are considered: a driller/rig worker, a production testing worker, and a compressor station/dehydrator maintenance worker. The production testing worker is likely to have the maximum exposure and thus the conditions particular to that worker are the focus of the worker-risk calculations. The assumptions for each worker type are described below.

Well development generally consists of hydrofracturing, well conditioning, and production testing. Liquids are removed from the well during this process, though the vast majority of these liquids originate from injection in the well during hydrofracturing, in contrast to native-formation fluid. Flaring of development fluids into the atmosphere can occur for about 30 days and it is assumed that the production testing worker is onsite during that entire period, breathing the flared $\mathrm{HTO}_{v}$, with exposed skin absorbing $\mathrm{HTO}_{v}$ from the humid air. This worker may also have incidental contact with $\mathrm{HTO}_{\text {liquid, }}$, but this is expected to be minimal as a result of industrial health and safety practices for liquid management (e.g., clothing requirements such as long-sleeved shirts; work gloves; safety glasses). Thus, the exposure duration for the production testing worker is 30 days.

For a driller/rig worker, exposure would occur as a well is drilled. Though it requires about 90 days to drill a Williams Fork well, the majority of this time is drilling through overlying formations. The vertical extent of the nuclear chimney in the subsurface is approximately $350 \mathrm{ft}$. At a relatively slow drilling rate of $100 \mathrm{ft} /$ day, there would be approximately four days during which fluids coming up hole on the rig could originate from the depth of the nuclear test chimney. Though fluids (gas and liquid) will be coming to the surface from the depth of concern for these four days of drilling, the worker does not necessarily have sustained exposure to $\mathrm{HTO}_{v}$ over that entire timeframe and any direct contact with liquids would only be incidental. Nonetheless, if four days of sustained exposure is assumed conservatively, this duration still represents a much smaller exposure duration than that of the production testing worker described above.

A compressor station/dehydrator maintenance worker is not usually in contact with the fluids involved at these facilities. Liquids are removed from the natural-gas stream at several locations in the process (e.g., at the wellhead, at compressor stations) but maintenance of these facilities is automated such that workers do not spend time in contact with the liquids or in enclosed spaces with water vapor equilibrated with the liquids. Gas and liquids at compressor stations and similar facilities also represent the accumulation of fluids from many wells such that any contaminant concentrations would be diluted and thereby prove to be insignificant with respect to exposures and relative to concentrations possible at 
the source well. As a result of these factors, the other worker scenarios entail higher potential exposure.

\section{Resident Exposure Scenario}

Tritiated methane (natural) gas $\left(\mathrm{CH}_{3} \mathrm{~T}_{\text {gas }}\right)$ was confirmed removed from the Rulison chimney by measurements made during the production testing in 1970 and 1971 (USAEC, 1973). Consequently, today natural gas use by the public is not a route of exposure. Additionally, as already described, any residual $\mathrm{HTO}_{\text {liquid }}$ that might be present in the gas would be insignificant, as a result of removal by dehydration equipment and dilution by gas from multiple wells prior to distribution. Therefore, there is no significant radionuclide source and no significant residential exposure as a result of distribution of the gas to a point of use, such as a home.

The resident that is the receptor of concern here is an individual living near the site of the newly drilled well. The resident exposure scenario parallels that of the worker in that flaring activities during well development and production testing are assumed to release tritium to the atmosphere and it is assumed that the resident inhales it and absorbs humid air through exposed skin. The exposure duration is 30 days, coinciding with the typical length of time for flaring during well development and production testing in the area. Both an adult and a child are considered.

Any exposure of the public to $\mathrm{HTO}_{\text {liquid }}$ removed from the gas stream is considered to be much smaller than the scenario involving exposure to flared gas. Water removed by dehydrators represents liquids from many gas wells, only a small fraction of which could be located adjacent to the Project Rulison test. In the unlikely event that tritium is present in water produced from one of the wells, it would be significantly diluted by liquids collected from other wells. Atmospheric dispersion of water vapor originating from collection ponds, and mixing with water vapor in the atmosphere from other sources, would cause additional reductions in concentration that would result in lower contaminant levels than would be present in flared gas.

\section{Exposure Concentration}

The worker and resident scenarios identified above describe inhalation and dermal exposure to $\mathrm{HTO}_{v}$ released during flaring. Though the screening risk calculation (estimate of potential current risk) and the consequence assessment (estimate of risk for bounding, unforeseen, conditions) employ the same exposure scenarios, the concentration of $\mathrm{HTO}_{v}$ used in these calculations differs.

\section{Exposure Concentration for Screening Risk Calculation}

Fluids from gas wells in the vicinity of Project Rulison are monitored for radionuclides by LM, and also by gas industry operators. The industry monitoring plan was developed in cooperation with the Colorado Oil and Gas Conservation Commission, and 
samples wells within 3 miles of the site. The LM program (USDOE, 2010b) emphasizes sampling wells with bottom-hole locations of 1 mile or less from the detonation. Monitoring focuses on produced water as the primary medium to sample; exchange between water vapor and liquid water occurs quickly such that tritium concentration should approach equilibrium between the two phases (in other words, if tritium is present in water vapor, it will also be present in liquid water in contact with that vapor). Produced water can be sampled at a liquid separator, where liquids are removed from the gas stream (point "a" in Figure 3).

The results from LM's monitoring program are available at http://www.lm.doe.gov/Rulison/Monitoring.aspx. To date, no analytical results have exceeded the screening level for tritium (the screening level is 2 times the nominal laboratory minimum detectable concentration, and is the concentration that triggers validation of results and possible increase in monitoring, USDOE, 2010b). In the absence of verifiable concentrations of tritium, the minimum detectable concentration (MDC) is used here for the screening risk calculation. The true exposure concentration is something less than the MDC, quite possibly zero, so using the MDC conservatively overestimates current risk.

The MDC for tritium in liquid-phase samples in the LM program is required to be $400 \mathrm{pCi} / \mathrm{L}$ (operationally, it is often somewhat lower). Given the exposure pathway, this value must be converted into an equivalent concentration in water vapor in air. The calculation of $\mathrm{HTO}_{v}$ from $\mathrm{HTO}_{\text {liquid }}$ is provided in Appendix A (specifically equation A-1). The MDC of $400 \mathrm{pCi} / \mathrm{L}$ equates to a $\mathrm{HTO}_{v}$ of approximately $6 \mathrm{pCi} / \mathrm{m}^{3}$ (using the summer humidity conditions described in Appendix A, see Table A-1). This $\mathrm{HTO}_{v}$ represents the concentration of tritiated vapor in air at equilibrium with the corresponding liquid, which is approximately what could be encountered within the flare stack, point " $b$ " in Figure 3. This is not the same as the concentration of $\mathrm{HTO}_{v}$ that either a worker or resident would be exposed to by breathing $\mathrm{HTO}_{v}$ exhausted from a flaring operation (point "c" in Figure 3). The 6 $\mathrm{pCi} / \mathrm{m}^{3}$ of $\mathrm{HTO}_{v}$ released to the atmosphere would be mixed with non-tritiated water vapor as a result of wind, buoyancy differences (especially for temperature differences during flaring), and diffusion. These processes are collectively known as dispersion and they can effectively and rapidly reduce concentrations by many orders of magnitude. Quantifying that reduction requires measurements of stack height, temperature, wind speed, etc., that will vary from location to location. Dispersion analysis for conditions specific to the Rulison test location concluded that the probable dilution factor for points downwind from the Rulison flare stack was a factor of $10^{5}$ to $10^{6}$ reduction from the released concentration (USAEC, 1973; Appendix G). Measurements are consistent with this dilution. Comparing concentrations of $\mathrm{HTO}_{v}$ calculated for the top of the flare stack with measurements of $\mathrm{HTO}_{v}$ at 8 groundbased sample locations close to the flare stack (Anspaugh et al., 1971) for the same time period identifies a million-fold dilution (see discussion in Appendix A). Monitoring of the gas stream and of air in the on-site and off-site environment typically reported concentrations of ${ }^{3} \mathrm{H}$ and ${ }^{85} \mathrm{Kr}$ from about one-millionth to 100 -millionth of their concentration in the gas (USAEC, 1972). Consistent with the nature of a screening calculation, the $6 \mathrm{pCi} / \mathrm{m}^{3}$ air 
concentration is adjusted here by the smallest dilution factor of $10^{5}$, resulting in an exposure concentration of $6 \times 10^{-5} \mathrm{pCi} / \mathrm{m}^{3}$.

\section{Exposure Concentration for Consequence Assessment}

The consequence assessment seeks to assess the risk if the unexpected occurs and there is a fracture connection between a future gas well and the Rulison nuclear chimney. A numerical flow and transport model simulated this scenario and concluded that no migration of tritium above background concentrations will occur beyond the Lot 11 boundary (Cooper et al., 2009, 2010). As a result, there are no calculations of predicted future concentrations to use for the consequence assessment. Instead of speculating about concentrations of $\mathrm{HTO}_{v}$ during flaring from a future well, measurements of $\mathrm{HTO}_{v}$ in atmospheric moisture from the actual flaring of gas at Project Rulison in 1970 are used for a bounding consequence assessment.

After the detonation, the nuclear chimney was intercepted by a well and production testing was conducted to assess the effectiveness of the test for enhancing natural-gas production. The produced gas was flared through a stack into the atmosphere and air sampling was conducted by project personnel, with independent atmospheric sampling conducted by the Colorado Department of Health (USAEC, 1973).

Review of project reports identified $560 \mathrm{pCi} / \mathrm{m}^{3}$ (Anspaugh et al., 1971) as the highest credible atmospheric tritium concentration reported during air monitoring of normal Project Rulison operations. This location was within "a few hundred feet of the flare stack" (Anspaugh et al., 1971) and the sample was collected during the first, high-rate, production test. Note that several higher values reported on October 5, 1970, actually represent rainout, meaning tritiated liquid water was released from the stack and collected by the monitoring equipment, rather than water vapor (Anspaugh et al., 1971). This occurred during the initial flaring as problems were encountered in adjusting the flow to achieve total vaporization (USAEC, 1973). The measurements for that day, therefore, do not represent water vapor available for inhalation. Using the value of $560 \mathrm{pCi} / \mathrm{m}^{3}$ as the concentration of $\mathrm{HTO}_{v}$ that can be inhaled and absorbed through exposed skin by both a worker and a resident is considered to be a very conservative assumption. This $\mathrm{HTO}_{v}$ concentration is an atmospheric measurement resulting from gas produced directly from the nuclear chimney shortly after the nuclear test, along with vaporized liquids also produced from the chimney (recall the earlier discussion that a large portion of the tritium released through the Rulison flare stack was disposal of liquid water produced from the chimney, not only gas products). Concentrations of radionuclides measured in the gas flared from the Project Rulison chimney in 1970 and 1971 decreased from this value as gas was produced and replaced by uncontaminated formation gas. Additionally, radioactive decay has reduced remaining radionuclide amounts. For example, the half-life of tritium $\left(t_{1 / 2}\right)$ is approximately 12.3 years, such that radioactive decay has reduced the concentration of tritium remaining in the subsurface to about a tenth of what it was in 1970. 


\section{Scenario Summary}

The exposure scenario assumes that $\mathrm{HTO}_{v}$ is encountered during drilling a new gas well adjacent to the Rulison nuclear test. It is assumed that $\mathrm{HTO}_{v}$ is released to the atmosphere for 30 days as a result of flaring during production testing operations at the well. The concentration of tritium in atmospheric $\mathrm{HTO}_{v}$ is assumed to be $6 \times 10^{-5} \mathrm{pCi} / \mathrm{m}^{3}$ for the screening risk assessment, based on the MDC of current produced-water monitoring activities, and estimated atmospheric dispersion. The concentration of $\mathrm{HTO}_{v}$ is assumed to be $560 \mathrm{pCi} / \mathrm{m}^{3}$ for the bounding consequence assessment, based on the highest measurement reported during the flaring of gas produced directly from the chimney during Project Rulison. Workers and residents are assumed to inhale air containing either $6 \times 10^{-5}$ or $560 \mathrm{pCi} / \mathrm{m}^{3}$ tritium concentration, and to absorb it through their exposed skin from humidity in the air. Workers may also have incidental splashes of $\mathrm{HTO}_{\text {liquid }}$, but that absorption, should it happen, is assumed minor compared to the skin absorption of atmospheric tritium. Though the worker and resident scenarios are similar, the risk calculations differ as a result of different assumed breathing rates. The details of these worker and resident potential risk calculations are presented in the next section.

\section{THE RISK CALCULATION PROCESS}

A screening calculation is performed for determining the occupational and public human-health lifetime excess morbidity cancer risks that could result from estimates of exposures to activity concentrations of $\mathrm{HTO}_{v}$ in air described in the exposure scenarios above. When "cancer" or "cancer risk" are used in this analysis, they always refer to morbidity, meaning that both fatal and nonfatal cancers are included. Occupational and public human-health cancer risk from exposures to $\mathrm{HTO}_{v}$ in air are estimated for worker and residents by multiplying together the following factors: 1) a concentration of $\mathrm{HTO}_{v}$ in air, 2) an estimate of the lifetime excess cancer morbidity risk coefficient, 3) a daily breathing rate for either a worker or a resident, 4) the dermal absorption factor that accounts for penetration of the skin by $\mathrm{HTO}_{v}$, and 5) the total duration of lifetime exposure.

This calculation is expressed mathematically and symbolically by Eq. (1), with the symbols and the units explained immediately following:

$R_{M B Y H T O_{v}-i n h+d e r m}^{i}=C_{H T O_{v}-a i r} \times M B Y R C_{H T O_{v}}^{i n h} \times\left(B R_{i} \times \mathrm{k}_{d e r m}\right) \times T E_{i}$,

where 


$$
\begin{aligned}
& R_{M B Y H T 0_{v}-\text { inh }+ \text { derm }}^{i}=\text { Lifetime excess morbidity }(M B Y) \text { cancer risk for individual worker } \\
& (i=w k r) \text { or resident }(i=\text { res adult or child }) \text { from both inhalation } \\
& \text { (inh) and dermal (derm) exposure to tritiated water vapor }\left(\mathrm{HTO}_{v}\right) \\
& \text { - expressed in units of lifetime attributable radiation cancer } \\
& \text { incidence (fatal and nonfatal); } \\
& C_{\mathrm{HTO}_{v} \text {-air }}=\text { activity concentration of } \mathrm{HTO}_{v} \text { in air }- \text { expressed in units of } \\
& \text { activity per unit volume of air }\left(\mathrm{pCi} / \mathrm{m}^{3}\right) \text {; } \\
& {\operatorname{MBY} R C_{H T O_{v}}^{i n h}}_{=}=\text {Central estimate of the age-averaged lifetime excess cancer } \\
& \text { morbidity (MBY) risk coefficient }{ }^{\dagger}(R C) \text { for inhalation of tritiated } \\
& \text { water vapor }\left(\mathrm{HTO}_{v}\right) \text { - expressed in units of lifetime attributable } \\
& \text { radiation cancer incidence (fatal and nonfatal) per unit of } \mathrm{HTO}_{v^{-}} \\
& \text {[radio]activity inhaled (e. g. , } R_{\mathrm{MBY}}^{\text {inh-HTO }} / \mathrm{pCi}_{\text {Нто }} \text { ) and for } \\
& \text { application to adult workers and adult residents is equal to } \\
& 5.62 \times 10^{-14} \mathrm{R} / \mathrm{pCi} \text { (as expressed in the Health Effects Summary } \\
& \text { Table (HEAST) }{ }^{\dagger} \text { and for application to child residents is the } \\
& \text { product of age-specific dose and risk per unit dose coefficients that } \\
& \text { yield the risk coefficient for a 1-y old child, which is equal to } 7.05 \\
& \times 10^{-13} \mathrm{R} / \mathrm{pCi} \text { for inhalation exposure; } \dagger^{\dagger \dagger} \\
& B R_{i} \times \mathrm{k}_{\text {derm }} \quad=\text { Breathing rate for } i=w k r \text {, or res adult or child-expressed in units } \\
& \text { of volume of air inhaled daily }\left(\mathrm{m}^{3} / \mathrm{d}\right) \text { and multiplied by a } \\
& \text { dimensionless constant }\left(\mathrm{k}_{\text {derm }}\right) \text { that is equal to a factor of } 2 \text { to } \\
& \text { account conservatively for dermal absorption of } \mathrm{HTO}_{v} \text { through the } \\
& \text { skin at a rate equal to the breathing rate (ATSDR, 2003); } \\
& T E_{i} \quad=\text { Total exposure over lifetime for } i=w k r \text {, or res adult or child }- \\
& \text { expressed in units of days over lifetime (d/lifetime) }
\end{aligned}
$$

The representative activity concentration for $\mathrm{HTO}_{v}$ in air used in Eq. (1) is described in the previous section of this report. The daily-average breathing rates selected for a worker $\left(30 \mathrm{~m}^{3} / \mathrm{d}\right)$ and for an adult resident $\left(22.2 \mathrm{~m}^{3} / \mathrm{d}\right)$, are considered to be representative of upper limits for adults (based on data compiled by OEHHA, 2000). The occupational adult breathing rate exceeds the residential one because the level of activity and metabolism required by adults performing drilling, production, and maintenance activities in the field are

\footnotetext{
${ }^{\dagger}$ Morbidity risk coefficient is described in Federal Guidance Report No. 13 and associated "HEAST User's Guide" (see USEPA, 1999) as the probability of both fatal and nonfatal radiogenic cancers per unit activity inhaled of a given radionuclide, and is expressed for tritiated water vapor $\left(\mathrm{HTO}_{v}\right)$ in Table 2.1 of the Federal Guidance Report No. 13 (see USEPA, 1999) as "1.52E-12 ( $\left.\mathrm{Bq}^{-1}\right)$ " and transformed in the "HEAST Radionuclide Table" (op. cit., USEPA, 1999) into a value of "5.6200e-14 Risk/pCi" (by multiplying units of $R / \mathrm{Bq}$ by $\left.3.7 \times 10^{-2} \mathrm{~Bq} / \mathrm{pCi}\right)$.

${ }^{\dagger}$ The maximum inhalation risk coefficient per unit dose for exposure to $\mathrm{HTO}_{v}$ occurs during childhood (between 0 to $20 \mathrm{y}$ ) from 0 to 1 year of age (see Appendix B). However, the inhalation morbidity risk coefficient per unit activity is derived as the product of the age-specific dose per unit activity ( $\mathrm{Sv} / \mathrm{pCi})$ and risk per unit dose $(\mathrm{R} / \mathrm{Sv})$ coefficients for the 1 -y old child.
} 
certain to be more demanding more consistently than in the case of an average healthy adult in a residential setting. The breathing rate used for a child $\left(5.2 \mathrm{~m}^{3} / \mathrm{d}\right)$ is the age-specific default value applicable to a 1-y old cited by Health Canada (1999).

Based on expert recommendations, the Agency for Toxic Substances \& Disease Registry (ATSDR) in a public health assessment (PHA) focusing on tritium released into the atmosphere and subsequent exposures chose to account for dermal absorption conservatively, by multiplying the breathing rate exposure by a factor of 2 (ATSDR, 2003). ${ }^{*}$ Although others, such as Hamby (1993), used a factor of only 1.5 for this purpose, in this screening assessment breathing rate is multiplied by the more conservative dimensionless constant of 2.0 in order to account for potential dermal absorption of $\mathrm{HTO}_{v}$. Although this approach for addressing the dermal exposure pathway is simplistic and semi-quantitative, it is nevertheless conceptually valid and conservative in keeping with the precautionary nature of a screening risk assessment.

The exposure time for all scenarios is 30 days, as described in the previous section.

\section{SCREENING ESTIMATES OF HUMAN-HEALTH RISK}

Screening estimates of potential human-health risk are summarized in Table 2 for the current conditions around the Rulison site, as identified from the monitoring data. Lifetime excess cancer risk was computed for both the worker and a resident adult and child based on a 30-d exposure duration. The details of each risk calculation are presented below.

\section{Worker Risk}

Worker risk is calculated for hypothetical inhalation and dermal exposures to $\mathrm{HTO}_{v}$ with a concentration of $6 \times 10^{-5} \mathrm{pCi} / \mathrm{m}^{3}$. This atmospheric vapor concentration is the equivalent of a liquid water tritium concentration of $400 \mathrm{pCi} / \mathrm{L}$, the $\mathrm{MDC}$ of current monitoring activities, dispersed in the atmosphere with a dilution factor of $10^{5}$. No monitoring measurements for liquids from wells within one mile of Rulison have exceeded the MDC for tritium, so the MDC is a conservatively high value.

An appropriate respiratory rate is identified $\left(30 \mathrm{~m}^{3} / \mathrm{d}\right)$ for metabolism associated with activities on a drilling platform or in performing activities related to production testing. Dermal absorption of $\mathrm{HTO}_{v}$ through exposed skin is also possible and it is accounted for by multiplying the breathing rate by a dimensionless constant of 2 (described in the previous section).

\footnotetext{
* Based on results of discussions between the authors M.W. Evans, PhD, and P. Charp, PhD, in the Division of Health Assessment and Consultation at the Agency for Toxic Substances \& Disease Registry (ATSDR) in the United States and subject-matter experts [R.V. Osborne, $\mathrm{PhD}$, at Ranasara Consultants, Inc., Deep River, Ontario, Canada (and former Director of the Health \& Environmental Sciences Division at Chalk River Laboratories, Ontario, Canada); and K. Eckerman, PhD, Leader of the Dosimetry Research Team at Oak Ridge National Laboratory, Oak Ridge, TN].
} 
Table 2. Estimated excess lifetime cancer morbidity risk (R/lifetime) for adult workers and nearby residents (adult and child), from inhalation and dermal exposure to $\mathrm{HTO}_{v}$ at (a) an air concentration derived from the detection limit used in the current monitoring program for tritium in liquid water $(400 \mathrm{pCi} / \mathrm{L})$, and (b) a hypothetical concentration of $\mathrm{HTO}_{v}$ in air represented by the maximum reported atmospheric concentration of $\mathrm{HTO}_{v}$ during flaring operations of gas produced directly from the Project Rulison nuclear chimney on October 28, 1970, from a sampling point within a few hundred feet of the flare stack (Anspaugh et al., 1971).

\begin{tabular}{|c|c|c|c|c|c|c|}
\hline $\begin{array}{c}\text { Exposed } \\
\text { individual }\end{array}$ & $\begin{array}{c}\text { Hypothetical } \\
\text { exposure } \\
\text { concentration for } \\
\left.\text { HTO } \text { in atmosphere }_{\left(C_{H^{2}}-\text { air }\right.} ; \mathrm{pCi} / \mathrm{m}^{3}\right)^{\mathrm{a}}\end{array}$ & $\begin{array}{c}\text { Estimated } \\
\text { total exposure } \\
\text { for individual } \\
\text { over lifetime } \\
\left(T E_{i} ;\right. \\
\text { d/lifetime }) \\
\end{array}$ & $\begin{array}{c}\text { Estimated daily } \\
\text { breathing rate } \\
\text { for exposed } \\
\text { individual }\left(B R_{i} ;\right. \\
\left.\mathbf{m}^{3} / \mathbf{d}\right) \\
\end{array}$ & $\begin{array}{c}\text { Constant by which } \\
B R_{i} \text { is multiplied in } \\
\text { order to account for } \\
\text { dermal absorption } \\
\text { of } \mathrm{HTO}_{v}\left(\mathrm{k}_{\text {derm }} ;\right. \\
\text { dimensionless) }\end{array}$ & $\begin{array}{c}\text { Inhalation morbidity } \\
\text { risk coefficient for } \\
\text { HTO }_{v}(\mathrm{Mby} R C ; \\
R / \mathbf{p C i})\end{array}$ & $\begin{array}{l}\text { Estimate of } \\
\text { risk per lifetime } \\
(R / \text { lifetime })\end{array}$ \\
\hline \multicolumn{7}{|c|}{ (a) Risk Assessment } \\
\hline Worker & $6 \times 10^{-5}$ & 30 & 30 & 2 & $5.62 \times 10^{-14}$ & $6 \times 10^{-15}$ \\
\hline Resident adult & $6 \times 10^{-5}$ & 30 & 22.2 & 2 & $5.62 \times 10^{-14}$ & $4 \times 10^{-15}$ \\
\hline Resident child ${ }^{a}$ & $6 \times 10^{-5}$ & 30 & 5.2 & 2 & $7.05 \times 10^{-13^{\mathbf{b}}}$ & $1 \times 10^{-14}$ \\
\hline \multicolumn{7}{|c|}{ (b) Consequence Assessment } \\
\hline Worker & $5.6 \times 10^{+02}$ & 30 & 30 & 2 & $5.62 \times 10^{-14}$ & $6 \times 10^{-08}$ \\
\hline Resident adult & $5.6 \times 10^{+02}$ & 30 & 22.2 & 2 & $5.62 \times 10^{-14}$ & $4 \times 10^{-08}$ \\
\hline Resident child ${ }^{a}$ & $5.6 \times 10^{+02}$ & 30 & 5.2 & 2 & $7.05 \times 10^{-13^{b}}$ & $1 \times 10^{-07}$ \\
\hline
\end{tabular}

${ }^{a}$ Maximum potential morbidity risk for exposure during childhood (from 0 to 20 y) occurs at 1 year of age (see Appendix B).

b The morbidity risk coefficient (per unit activity) for inhalation exposure to $\mathrm{HTO}_{v}$ for a 1-y old child is derived as the product of age-specific risk per unit dose (R/Sv) and dose per unit activity (Sv/pCi) coefficients for this age category (see Appendix B, Table B-1). 
The risk coefficient considered applicable is taken from Federal Guidance No. 13 (USEPA, 1999), as expressed in the HEAST summary table. The dimensions of this parameter are lifetime excess morbidity (both fatal and nonfatal) cancer risk per unit activity of $\mathrm{HTO}_{v}$ (see Table 2a).

The highest estimated worker lifetime excess cancer risk for inhalation and dermal exposure over $30 \mathrm{~d}$ to the atmospheric concentration of $\mathrm{HTO}_{v}$ of $6 \times 10^{-5} \mathrm{pCi} / \mathrm{m}^{3}$ is presented in the last column of Table $2 \mathrm{a}$. The resulting risk value is $6 \times 10^{-15}(6$ per $1,000,000,000,000,000)$.

\section{Resident Risk}

For a resident adult and child, the exposure concentration for $\mathrm{HTO}_{v}$ in air is again based on the detection limit for tritium in liquid water in the current LM monitoring program, converted to an equivalent water vapor concentration, and dispersed as released from a flare stack. This dispersed atmospheric concentration is $6 \times 10^{-5} \mathrm{pCi} / \mathrm{m}^{3}$.

For the resident adult, the applicable breathing rate is multiplied by a factor of 2 (ATSDR, 2003) in order to account conservatively for dermal absorption of $\mathrm{HTO}_{v}$ by exposed skin. As noted earlier, the respiratory rate of $22.2 \mathrm{~m}^{3} / \mathrm{d}$ is less than for a worker because the resident adult is not considered to be performing the same degree of continuous activity and exertion workers are certain to experience in executing field tasks daily. Similarly, for a resident child, the breathing rate is also multiplied by a factor of 2 to account conservatively for dermal absorption. As noted previously, the breathing rate for a 1-y old child $\left(5.2 \mathrm{~m}^{3} / \mathrm{d}\right)$ is applied because the risk is greatest for this age-specific category (see Appendix B).

As in the case for the worker, the risk coefficient considered applicable for the resident adult is taken from Federal Guidance No. 13 (USEPA, 1999), as expressed in the HEAST summary table. The dimensions of this parameter are lifetime excess morbidity (both fatal and nonfatal) cancer risk per unit activity of $\mathrm{HTO}_{v}$ (see Table 2a).

The estimated resident lifetime excess cancer risk based on inhalation and dermal exposure over $30 \mathrm{~d}$ to the atmospheric concentration of $\mathrm{HTO}_{v}$ of $6 \times 10^{-5} \mathrm{pCi} / \mathrm{m}^{3}$ appears in the last column of Table $2 \mathrm{a}$. The resulting risk value for the adult resident is $4 \times 10^{-15}$ ( 4 per $1,000,000,000,000,000)$.

For the same exposure duration as the worker ( $30 \mathrm{~d})$ the value for risk for an adult resident is about 1.5 times lower, the reason being that the $B R_{r e s}$ and $B R_{w k r}$ differ by about a factor of 1.5 (i.e., 22.2 vs. $30 \mathrm{~m}^{3} / \mathrm{d}$; for resident and worker, respectively).

The morbidity risk coefficient per unit activity for the resident child is derived in Appendix B (see Table B-1) and is expressed as $7.05 \times 10^{-13} \mathrm{R} / \mathrm{pCi}$. The estimated lifetime excess cancer risk for the same exposure duration as an adult resident is $1 \times 10^{-14}$ ( 1 per $100,000,000,000,000$ ), a factor of 2.5 times greater than the adult risk due to differences in risk coefficients and breathing rates. 


\section{Sensitivity of Risk Assessment Results to Parameter Uncertainty}

The values of each parameter in the equation used to compute excess lifetime cancer risk (Eq. 1) have some uncertainty associated with them. Evaluating the impact of that uncertainty on the risk calculation can help determine whether or not an investment in reducing uncertainty is needed to better define the risk. One approach for evaluating uncertainty is to define a range for each parameter and perform the calculation hundreds or thousands of times, randomly selecting values from all the parameter ranges, resulting in a statistical distribution of possible risk values. This quantitative approach is not employed here, but instead uncertainty is evaluated in each parameter individually and the sensitivity of the computed risk is assessed. This is consistent with the screening nature of this analysis. One consequence of this simpler approach is that the focus is only on the upper bound of uncertainty, meaning values that would increase the calculated risk. It is important to recognize that the uncertainty in parameters also includes values that would result in risk much lower than reported here. Each individual parameter (atmospheric exposure concentration, breathing rate, dermal-absorption multiplier, risk coefficient, and exposure duration) is examined below, along with the significance the upper bound of uncertainty could have on the outcome of excess lifetime cancer risk.

\section{Atmospheric Concentration}

The sources of uncertainty for the atmospheric concentration of $\mathrm{HTO}_{v}$ are dispersion, the conversion from liquid to vapor values, and measurement uncertainty. The largest of these is the dispersion factor, which is reported to vary over several orders of magnitude at the Rulison site, but the lowest end of that range is already used in the analysis (the lower value giving less dispersion and higher concentration). Additional uncertainty is introduced by the assumptions required to convert from the liquid concentration to that in a vapor (for example, the assumption of humidity). The impact of these can be seen in Appendix A where summer and winter conditions are contrasted. Given that the summer conditions are already assumed here, leading to higher atmospheric concentrations, uncertainty in atmospheric conditions for the vapor conversion cannot reasonably contribute more than a factor of two or three. The atmospheric concentration of $\mathrm{HTO}_{v}$ used here is related to the $\mathrm{MDC}$ for production water in the monitoring program of $400 \mathrm{pCi} / \mathrm{L}$. The uncertainty in the laboratory analysis for $\mathrm{HTO}_{\text {liquid }}$ is reported as less than $200 \mathrm{pCi} / \mathrm{L}$. Calculating an atmospheric concentration based on a liquid concentration of 600 pCi/L ( 400 plus 200 ), would increase the calculated risk by 1.5 times. Considering this combined uncertainty in the atmospheric concentration as a factor of 3 to 5 , yields a corresponding lifetime excess cancer risk for the worker and residents (both adult and child) that remains less than $1 \times 10^{-6}$.

\section{$\underline{\text { Risk Coefficient }}$}

According to Pawel et al. (2007), “ ... most risk coefficients for inhalation of radionuclides are determined within a factor of 5 or less by current information." This conclusion applies specifically to the risk coefficients for inhaled $\mathrm{HTO}_{v}$ by the adult worker and resident 
(based on the assignment of the mortality risk coefficient for inhaled tritium vapor to the narrowest of the relatively broad, semi-quantitative "uncertainty categories" used to address uncertainty in the risk coefficient for this radionuclide and exposure mode). Therefore, on the basis of this uncertainty analysis for the risk coefficient for inhalation of tritium vapor, the value of MbyRC applicable to the adult worker and resident might be greater by at most a factor of 5, based on the application of the models used for its derivation. Accordingly, an increase by a factor of 5 in the value of the Mby $R C$ would yield a corresponding lifetime excess cancer risk for both worker and residents that would still be less than $1 \times 10^{-6}$.

For the child, the uncertainty in the derived risk coefficient per unit activity may range from 1 to 10 and is likely to be a factor of 2 (see Appendix B). Conservatively considering the factor of 10 , the corresponding lifetime risk for a 1-y old child will remain less than $10^{-6}$.

\section{Breathing Rate}

The worker and resident breathing rates used to compute worker and adult resident excess lifetime cancer risk are $30 \mathrm{~m}^{3} / \mathrm{d}$ and $22.2 \mathrm{~m}^{3} / \mathrm{d}$, respectively, whereas the child rate for a one-year old is $5.2 \mathrm{~m}^{3} / \mathrm{d}$. According to data compiled by OEHHA (2000), a maximum overall breathing rate equivalent for an adult is estimated to be $693 \mathrm{~L} /(\mathrm{kg} \cdot \mathrm{d})$, which converts to 48.5 $\mathrm{m}^{3} / \mathrm{d}$ for a $70 \mathrm{~kg}$ individual. This breathing rate is a factor of more than 1.5 times greater than the worker estimate and almost 2.2 times greater than the resident estimate. If the worker and resident estimates of risk per lifetime that appear in the last columns in Table 2 are multiplied by a factor of 1.5 and 2.2, for worker and resident respectively, the result in each case remains a risk level that does not exceed $1 \times 10^{-6}$.

The equivalent analysis for the child breathing rate $\left(5.2 \mathrm{~m}^{3} / \mathrm{d}\right)$, based on a maximum overall breathing rate of $13.4 \mathrm{~m}^{3} / \mathrm{d}$ for an $18 \mathrm{~kg}$ child $\leq 12 \mathrm{y}$ of age (OEHHA, 2000), suggests an uncertainty factor of 2.6 times. Even when multiplying the risk by this factor, the cancer risk for the child remains below $10^{-6}$.

\section{$\underline{\text { Dermal-Absorption Constant }}$}

The dermal-absorption constant is already at its maximum value of 2 (a factor of 1.5 has been used by others). Consequently, this value is not considered to be associated with any uncertainty relative to an alternative less realistic maximum.

\section{Exposure Duration}

The exposure duration is estimated based on the typical amount of time a gas well completed in the Williams Fork Formation undergoes well development and production testing involving flaring of gas in the atmosphere. Estimated at 30 days, the duration of that activity may vary from well to well based on formation characteristics and hydraulic fracturing specifics. However, with natural gas as a commercial commodity, there is business interest in limiting the duration of flaring such that it is unlikely to continue more than two or three times the 30 days assumed here. 
Another aspect of exposure duration is the assumption that only one contaminated well is encountered. Given recent drilling intensity in the area, many wells could be drilled in the area surrounding Lot 11 . The potential wells of most interest, considering current drilling practices and the predominant east-west fracture trend controlling reservoir drainage, are four wells in each of the lots due east and west, and two wells in each of the six lots north and south of lot 11 [this is coincident with the more intense monitoring frequency zone proposed by LM (USDOE, 2010b), Figure 4].

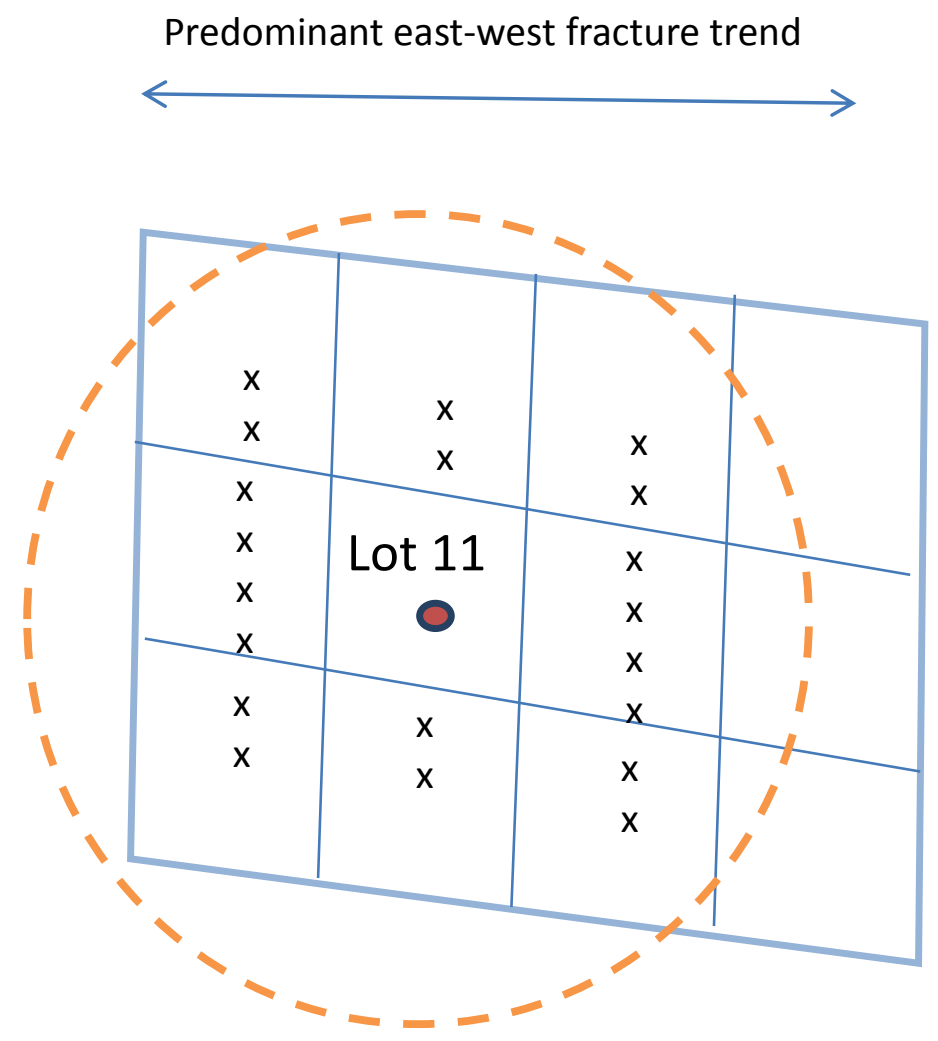

Figure 4. Sketch map of the Rulison nuclear test location, shown as the red circle in Lot 11. Lot boundaries are in blue and a half-mile radius from the test is shown in orange. Hypothetical new gas wells are shown by an " $x$ " in the surrounding lots, located per current well drilling practice in the area.

Given that fracture connection between the chimney and one well is considered highly improbable based on hydrofracturing and nuclear fracturing characteristics, it is essentially impossible for all of the surrounding wells to produce gas associated with the Rulison test. Nonetheless, if the noted surrounding wells in the half-mile zone encountered tritium at the MDC, were flared for 30 days one after another, and the same worker was present throughout, the exposure duration would increase by 20 times. To have the same increase for the residents unrealistically demands that the weather conditions continually change such that the residence remains downwind of every well. Combining the uncertainty in the length of time for flaring a 
single well with this unrealistic multiple well scenario would result in a factor of 60 increase (3 times 20) in the total exposure (TE) duration for a worker and residents. The corresponding level of risk for all receptors would remain less than $1 \times 10^{-6}$.

\section{Effect of Compounding Upper Bounds of Parameter Uncertainties}

The effect of compounded parameter uncertainties on excess lifetime morbidity cancer risk outcomes is determined by multiplying the respective risk estimates computed in the righthand column of Table 2 by the product of the estimated uncertainties for each parameter with respect to an upper bound. This compounded uncertainty factor is about 1.5 times larger for the adult resident than for the worker because of the larger uncertainty estimated for the resident breathing rate (e.g., for worker the product of compounded uncertainties is $\leq 5$ for $\mathrm{C}_{H T O_{\text {-air }}} \times \leq 5$ for $\mathrm{Mby} R C \times \leq 1.5$ for $\mathrm{BR}_{w k r} \times \leq 60$ for a total uncertainty factor of 2250 ; and for the residents the product of compounded uncertainties is $\leq 5$ for $\mathrm{C}_{H T O_{v} \text {-air }} \times \leq 5$ for $\mathrm{Mby} R C \times \leq 2.2$ for $\mathrm{BR}_{\text {res- }}$ adult $\times \leq 60 \mathrm{TE}$ for a total factor of 3300). The compounded uncertainty for the resident child is $\leq 5$ for $\mathrm{C}_{\mathrm{HTO}_{v} \text {-air }} \times \leq 10$ for MbyRC $\times \leq 2.6$ for $\mathrm{BR}_{\text {res-child }} \times \leq 60 \mathrm{TE}$ for a total uncertainty factor of 7800. The multiplication of worker and adult and child resident risk values by even the maximum of these compounded factors reveals from a screening perspective that the resulting risks, which now must be considered unrealistically conservative, remain within the risk range considered by regulatory agencies to be virtually safe or de minimis (i.e., from $10^{-4}$ to $\leq 10^{-6}$ ). As a result, there may be no need to better quantify the uncertainty in the screening risk calculation beyond the conservative estimates used here.

\section{CONSEQUENCE ASSESSMENT FOR HUMAN-HEALTH RISK}

The preceding risk analysis is based upon current monitoring data. The following consequence analysis is a conservative estimate of the risk if the unexpected occurs and there is a direct connection between the nuclear chimney and a future well. The calculations are performed in the interest of providing context to decision makers when assessing the adequacy of monitoring and institutional controls. Not only is a well intercepting the nuclear chimney an incredible event, the consequence assessment is additionally conservative in the assumed exposure concentration, based on the highest value measured during atmospheric monitoring, which was at the beginning of the Rulison production testing in 1970. Radionuclide concentrations within the chimney itself are much reduced from 1970, as a result of the radionuclides removed from the chimney by production testing, as well as radioactive decay.

Potential human-health risk associated with the consequence assessment is summarized in Table $2 \mathrm{~b}$ for an exposure based on monitoring data during flaring activities for natural gas produced directly from the Rulison chimney in the 1970s. Lifetime excess cancer risk was computed for both the worker and resident based on a 30-d exposure duration, a period of time 
much longer than would be expected if the assumed radionuclide concentration was detected by monitoring. The details of each risk calculation are presented below.

\section{Worker Risk}

Worker risk is calculated for hypothetical inhalation and dermal exposures to a $\mathrm{HTO}_{\mathrm{v}}$ concentration of $560 \mathrm{pCi} / \mathrm{m}^{3}$. This concentration is the maximum reported from measurements during production testing and flaring of gas from the Project Rulison nuclear chimney (Anspaugh et al., 1971).

An appropriate respiratory rate is identified $\left(30 \mathrm{~m}^{3} / \mathrm{d}\right)$ for metabolism associated with activities on a drilling platform or in performing activities related to production testing. However, dermal absorption of $\mathrm{HTO}_{v}$ through exposed skin is also possible and it is necessary to account for that pathway of exposure too (Peterson, 2008; and Hamby, 1993). As noted previously, it is considered conservative to assess the dermal absorption of HTO by the skin as being equal to that occurring in the lungs as a result of inhalation. Consequently, the breathing rate is multiplied by a dimensionless constant of 2 (see Table $2 b$ ).

The risk coefficient considered applicable is taken from Federal Guidance No. 13 (USEPA, 1999), as expressed in the HEAST summary table. The dimensions of this parameter are lifetime excess morbidity (both fatal and nonfatal) cancer risk per unit activity of $\mathrm{HTO}_{v}$ (see Table 2b).

The highest estimated worker lifetime excess cancer risk for inhalation and dermal exposure over $30 \mathrm{~d}$ to the atmospheric concentration of $\mathrm{HTO}_{v}$ of $560 \mathrm{pCi} / \mathrm{m}^{3}$ is presented in the last column of Table $2 \mathrm{~b}$. The resulting risk value is $6 \times 10^{-8}$ (6 per 100,000,000).

\section{Resident Risk}

For an adult and child resident, the exposure concentration for $\mathrm{HTO}_{v}$ in air is again based on the maximum concentration of $\mathrm{HTO}_{v}$ measured in the atmosphere during flaring operations conducted at the time of Project Rulison, $560 \mathrm{pCi} / \mathrm{m}^{3}$ (Anspaugh et al., 1971).

For the adult and child resident, the applicable breathing rate is multiplied by a factor of 2 (ATSDR, 2003) in order to account conservatively for dermal absorption of $\mathrm{HTO}_{v}$ by exposed skin. As noted earlier, the adult resident respiratory rate of $22.2 \mathrm{~m}^{3} / \mathrm{d}$ is less than for a worker because the resident is not considered to be performing the same degree of continuous activity and exertion workers are certain to experience in executing field tasks daily, and for a child, the breathing rate is that of a $1-y$ old $\left(5.2 \mathrm{~m}^{3} / \mathrm{d}\right)$.

As in the case for the worker, the risk coefficient considered applicable is taken from Federal Guidance No. 13 (USEPA, 1999), as expressed in the HEAST summary table. The dimensions of this parameter are lifetime excess morbidity (both fatal and nonfatal) cancer risk per unit activity of $\mathrm{HTO}_{v}$ (see Table 2b). The child risk coefficient is derived in Appendix B and equates to $7.05 \times 10^{-13} \mathrm{R} / \mathrm{pCi}$. 
The estimated resident lifetime excess cancer risk based on inhalation and dermal exposure over $30 \mathrm{~d}$ to the atmospheric concentration of $\mathrm{HTO}_{v}$ of $560 \mathrm{pCi} / \mathrm{m}^{3}$ appears in the last column of Table $2 \mathrm{~b}$. The resulting risk value is $4 \times 10^{-8}$ (4 per 100,000,000) for the adult resident, and $1 \times 10^{-7}$ for the child resident ( 1 per 10,000,000).

For the same exposure duration as the worker (30 d) the value for risk for an adult resident is about 1.5 times lower, the reason being that the $B R_{r e s}$ and $B R_{w k r}$ differ by about a factor of 1.5 (i.e., 22.2 vs. $30 \mathrm{~m}^{3} / \mathrm{d}$; for resident and worker, respectively). The risk for the child resident is 2.5 times higher than the adult resident as a result of the differences in risk coefficients and breathing rates.

\section{IMPLICATIONS FOR MONITORING}

The activity concentration in air of $\mathrm{HTO}_{v}$ can be related to the activity concentration of tritium (as HTO) in associated liquid-phase water in order to establish health protective riskbased action levels for monitoring production water, as discussed in the "Rulison Monitoring Plan" (USDOE, 2010b). This is possible as a result of the rapid equilibrium obtained between tritiated water vapor and liquid water. By measuring the concentration of one phase, the concentration in the other phase can be determined. For example, the concentration of $\mathrm{HTO}_{v}$ in air that would correspond to a human health risk of $1 \times 10^{-6}$ in the exposure scenario can be converted to an equivalent concentration of tritium in liquid water $\left(\mathrm{HTO}_{\text {liquid }}\right)$, using the equations presented in Appendix A. If a valid measurement of tritium in product water $\left(\mathrm{HTO}_{\text {liquid }}\right)$ from a well near Project Rulison were to exceed a risk-based action level (i.e., activity concentration), then the well in question can be shut-in until the situation can be assessed further, and nearby wells might have their sampling frequency increased.

The maximum activity concentration of $\mathrm{HTO}_{v}$ in air that is associated with a $1 \times 10^{-6}$ lifetime excess cancer risk for the worker and resident scenarios can be found in Table A-2 of Appendix A. For the worker exposure scenario, the air concentration equivalent to this level of risk is $9.9 \times 10^{3} \mathrm{pCi} / \mathrm{m}^{3}$. For the resident adult exposure scenario, the activity concentration of $\mathrm{HTO}_{v}$ in air that is associated with a $1 \times 10^{-6}$ lifetime excess cancer risk is $1.5 \times 10^{4} \mathrm{pCi} / \mathrm{m}^{3}$. The activity concentration of $\mathrm{HTO}_{v}$ in air associated with a $1 \times 10^{-6}$ lifetime excess cancer risk for the resident child exposure scenario is $4.6 \times 10^{3} \mathrm{pCi} / \mathrm{m}^{3}$. The lowest of these air concentrations, $4.6 \times 10^{3} \mathrm{pCi} / \mathrm{m}^{3}$, is conservatively carried forward in the subsequent discussion.

Converting the concentration of $\mathrm{HTO}_{v}$ in air equating to a $1 \times 10^{-6}$ cancer risk for the resident child to an equivalent concentration of tritium as liquid water $\left(\mathrm{HTO}_{\text {liquid }}\right)$, should begin by accounting for the dispersion of $\mathrm{HTO}_{v}$ between the release point (flare stack) and the exposure location where the individual breathes the air. That probable dilution factor of $10^{5}$ to $10^{6}$ (USAEC, 1973) is ignored at this point in the interest of identifying a protective action level (triggering action prior to any potential health risk). Neglecting dispersion, the concentration of $\mathrm{HTO}_{v}$ in air of $4.6 \times 10^{3} \mathrm{pCi} / \mathrm{m}^{3}$ equates to an activity concentration for $\mathrm{HTO}_{\text {liquid }}$ of $3.1 \times 10^{5}$ 
$\mathrm{pCi} / \mathrm{L}$ for a child resident during summer atmospheric conditions at Rulison (see Table A-2 in Appendix A for values for winter, as well as values for worker and resident adult exposure). Accordingly, the lowest concentration in water identified here, $3.1 \times 10^{5} \mathrm{pCi} / \mathrm{L}$, is one option for an action level that is health protective during monitoring.

Because dispersion is neglected in the calculation above, if monitoring identifies concentrations of $\mathrm{HTO}_{\text {liquid }}$ in production water at a concentration of $3.1 \times 10^{5} \mathrm{pCi} / \mathrm{L}$, a recommended first action is to collect and measure $\mathrm{HTO}_{v}$ from the atmosphere where workers and residents are likely to be located during flaring. It is expected that $\mathrm{HTO}_{v}$ concentrations will be well below the level associated with a risk value of $10^{-6}$ (likely by a factor of a million, given atmospheric dispersion information), so there would be opportunity for response actions, if necessary, in advance of significant exposure.

\section{CONCLUSIONS}

A probability range from $10^{-4}$ to $\leq 10^{-6}$ of excess lifetime cancer risk generally is considered by regulatory agencies to be negligible or too small to be of societal concern (and is equated with the de minimis principal or "virtually safe" concept). While some may argue that the notion of negligible risk is vague and should not be subject to literal interpretation, the principle is based on selecting a sufficient threshold of improbability so that risks at or below that level can be ignored for purposes of decision making (Martin, 2002). The concept of de minimis risk has been adopted by the USEPA (2010; 40 CFR 300) for managing responsibly environmental, health, and safety risks for compliance, and so it will be used here for considering the magnitude of risk for the worker and resident scenarios with respect to potential emissions of $\mathrm{HTO}_{v}$ into air. The screening calculations of current potential risk, as well as a bounding consequence analysis of possible future risk, presented here both conclude that lifetime excess morbidity cancer risk is at magnitudes below 1 per million (i.e., $<<1 \times 10^{-6}$ ) for a worker and for adult and child resident scenarios.

Given that historic monitoring data are used here for the consequence assessment, it should be noted that during Project Rulison activities after the nuclear detonation, including drill back, gas sampling, gas-production testing, and gas flaring, human health and safety monitoring revealed “ ... no personnel radiation exposures” (USAEC, 1973).

It is informative to compare the concentrations used for performing these screening calculations of risk with those that are considered health protective and published in the regulatory literature. For workers, the USDOE (2009), USNRC (2007), and State of Colorado Department of Public Health and Environment (CHPDE, 2005) all indicate that occupational exposure to tritium in air should not exceed the derived air concentration (DAC) of $2 \times 10^{7} \mathrm{pCi} / \mathrm{m}^{3}$, a value much higher than the $6 \times 10^{-5} \mathrm{pCi} / \mathrm{m}^{3}$ used for this screening risk assessment, and also higher than the $5.6 \times 10^{2} \mathrm{pCi} / \mathrm{m}^{3}$ used in the consequence assessment. 
For residents, the atmospheric exposure concentration of $\mathrm{HTO}_{v}$ used in the consequence assessment of $5.6 \times 10^{2} \mathrm{pCi} / \mathrm{m}^{3}$ also is well below regulatory concentration limits for public health protection. For example, for members of the public, USDOE (1993), USNRC (2007), and CDPHE (2005) set guidance at a concentration in air of $1 \times 10^{5} \mathrm{pCi} / \mathrm{m}^{3}$. Even more importantly, the concentration used in this consequence assessment is also below the more restrictive

concentration limit of $1.5 \times 10^{3} \mathrm{pCi} / \mathrm{m}^{3}$ specified by USEPA (1989) for $\mathrm{HTO}_{v}$ in air as part of the National Emission Standards for Hazardous Air Emissions (applicable to radionuclides emitted from federal facilities of this category).

In conclusion, this screening assessment of human-health risk and bounding consequence assessment indicate that worker and resident (adult and child) health risk from inhalation and dermal exposure to tritium in water can be considered de minimis as a result of current and future natural-gas drilling near Project Rulison in Western Colorado. Additionally, monitoring of produced water at a concentration limit consistent with such de minimis risk will ensure that the future recovery of natural gas near Project Rulison will be protective of occupational and public health. These findings provide a human health perspective to consider along with data from past site activities, forecasts of predicted contaminant behavior, and ongoing monitoring, for site stewardship.

\section{REFERENCES}

Agency for Toxic Substances \& Disease Registry (ATSDR). 2003. Dermal Absorption Exposure (of §3: Exposure Assessment and Dose Estimation) in Public Health Assessment (PHA): Community Exposures To The 1965 And 1970 Accidental Tritium Releases, Lawrence Livermore National Laboratory, Main Site (USDOE), Livermore, Alameda County, California, prepared by M.W. Evans and P. Charp, Federal Facilities Assessment Branch, Division of Health Assessment and Consultation, Agency for Toxic Substances and Disease Registry, Atlanta, GA (Available at URL: http://www.atsdr.cdc.gov/HAC/pha/ PHA.asp?docid=37\&pg=0; December 2010).

Anspaugh, L.R., J.J. Koranda, and W.L. Robison, 1971, Environmental Aspects of Natural Gas Stimulation Experiments with Nuclear Devices. In Nelson, D.J. (ed.), National Symposium on Radioecology, Oak Ridge, Tennessee, CONF-710501--P1, pp. 37-52.

Colorado Department of Public Health and Environment (CDPHE). 2005. Part 4-Standards for Protection Against Radiation, in State Board of Health Rules and Regulations Pertaining to Radiation Control, Department of Public Health and Environment, Hazardous Material and Waste Management Division, Denver, CO (available December 2010 at http://www. cdphe.state.co.us/regulations/index.html and http://www.cdphe.state.co.us/regulations/ radiationcontrol/10070104protectionagainstrad.pdf and Tables 4B1and 4B2 at http://www.cdphe.state.co.us/regulations/radiationcontrol/10070104app.pdf). 
Cooper, C., M. Ye, and J. Chapman. 2007. Tritium Transport at the Rulison Site, A NuclearStimulated Low-Permeability Natural Gas Reservoir. Desert Research Institute, Division of Hydrologic Sciences Publication No. 45224 prepared for the Office of Legacy Management, U.S. Department of Energy, Grand Junction, CO, DOE/NV/13609-54 and DOE-LM/1521 2007.

Cooper, C.A., Ming Ye, J.B. Chapman, and R.A. Hodges. 2009. Addendum: Tritium Transport at the Rulison Site, a Nuclear Stimulated Low-Permeability Natural Gas Reservoir. Desert Research Institute Letter Report, prepared for Stoller Corporation and United States Department of Energy, Office of Legacy Management, Grand Junction, CO.

Cooper, C.A., J.B. Chapman, Y. Zhang, R. Hodges, and M. Ye. 2010. Update of Tritium Transport Calculations for the Rulison Site: Report of Activities and Results During 2009-2010. Desert Research Institute Letter Report prepared for Stoller Corporation and United States Department of Energy, Office of Legacy Management, Grand Junction, CO.

Fort, C.W., V.E. Andrews, and A. Goldman. 1972. Comparison of Freeze-Out and Adsorption Techniques for Collection of Atmospheric Tritium as HTO. National Environmental Research Center (NERC), United States Environmental Protection Agency, Las Vegas, NV; NERC-LV-539-12.

Hamby, D.M. 1993. A Probabilistic Estimation of Atmospheric Tritium Dose, Health Phys. 65(1), 33-40.

Health Canada, Joint Working Group of Radiation Protection Bureau (1999), Summary of Recommended Assessment Parameters, Health Canada, Ottawa, Ontario, Canada, http://www.hc-sc.gc.ca/ewh-semt/pubs/radiation/dose/summary-resume-eng.php\#table1 and http://www.hc-sc.gc.ca/ewh-semt/pubs/radiation/dose/index-eng.php.

Martin, P. 2002. What is a de minimis Risk? Risk Manag. 4(2), 47-55.

Nork, W.E., and P.R. Fenske. 1970. Radioactivity In Water-Project Rulison. Prepared for U.S. Atomic Energy Commission, Nevada Operations Office, Las Vegas, NV, by Teledyne Isotopes, Palo Alto, CA, NVO-1229-131, 20p.

Office of Environmental Health Hazard Assessment (OEHHA) 2000. Air Toxics Hot Spots Program Risk Assessment Guidelines Part IV-Technical Support Document: Exposure Assessment and Stochastic Analysis, Office of Environmental Health Hazard Assessment, California Environmental Protection Agency, Oakland, CA, Final Draft September 2000; Available January 2011 at URL: http://www.oehha.ca.gov/air/hot_spots/finalStoc.html\#download.

Pawel, D.J., R.W. Leggett, K.F. Eckerman, and C.B. Nelson. 2007. "Uncertainties in Cancer Risk Coefficients for Environmental Exposure to Radionuclides-An Uncertainty Analysis for Risk Coefficients Reported in Federal Guidance Report No. 13," Oak Ridge National Laboratory, Oak Ridge, TN, ORNL/TM-2006/583; Available January 2011 at URL: http://www.epa.gov/rpdweb00/docs/assessment/ornl-tm-2006-583.pdf.

Peterson, S-R. 2008. Dose to the Public from Tritium Released to the Atmosphere from the Livermore Site of the Lawrence Livermore National Laboratory, 1953 through 2005, Health Phys. 95(2), 190-202. 
Smith Jr., C.F., 1971. Gas Analysis Results For Project Rulison Production Testing Samples. Lawrence Livermore Laboratory, UCRL-51153, 24p.

United States Atomic Energy Commission (USAEC). 1972. Project Rulison Final Operational Radioactivity Report Production Tests. Prepared by R.L. Gotchy, Peaceful Applications Division, United States Atomic Energy Agency, Nevada Operations Office, Las Vegas, NV, NVO-112, PNE-R-57, 71p.

United States Atomic Energy Commission (USAEC).1973. Project Rulison Manager's Report. Nevada Operations Office, Las Vegas, NV, NVO-71, PNE-R-63, 247p.

United States Department of Energy (USDOE). 1993. Radiation Protection of the Public and the Environment-DOE ORDER 5400.5. United States Department of Energy, Washington, DC; Change 2, 7 January 1993 (available December 2010 at https://www.directives. doe.gov/directives/current-directives/5400.5-BOrder-c2/view).

United States Department of Energy (USDOE). 2009. Appendix A to Part 835-Derived Air Concentrations (DAC) for Controlling Radiation Exposure to Workers at DOE Facilities, in Title 10 of Code of Federal Regulations (CFR): Energy; Part 835-Occupational Radiation Protection (10 CFR 835), e-CFR, National Archives and Records Administration (NARA), Washington, DC; published in Fed. Regist. 74, 18116, 21 April 2009.

United States Department of Energy (USDOE). 2010a. FINAL: Rulison Path Forward. U.S. Department of Energy, Office of Legacy Management, Grand Junction, CO, LMS/RUL/S04617.

United States Department of Energy (USDOE). 2010b. Rulison Monitoring Plan., U.S. Department of Energy, Office of Legacy Management, Grand Junction, CO, LMS/RUL/S06178.

United States Environmental Protection Agency (USEPA). 1989. §3. Table of Concentration Levels in Appendix E to Part 61-Compliance Procedures Methods for Determining Compliance with Subpart I, of Title 40 of Code of Federal Regulations (CFR): Protection of Environment; Part 61-National Emission Standards for Hazardous Air Pollutants (40 CFR 61); Subpart I-National Emission Standards for Radionuclides Emissions from Federal Facilities Other Than Nuclear Regulatory Commission Licensees and Not Covered by Subpart H, published in Fed. Regist. 54, 51711, December 15, 1989; e-CFR, National Archives and Records Administration (NARA), Washington, DC (40 CFR 61 Revised as of January 2010; see also $\$ 61.102$ of 40 CFR 61 for 10 mrem/y Dose Limit that corresponds to Concentration Levels appearing in Table 2 of Appendix E).

United States Environmental Protection Agency (USEPA). 1999. Federal Guidance Report No. 13-Cancer Risk Coefficients for Environmental Exposure to Radionuclides. Prepared by K.F. Eckerman, R.W. Leggett, C.B. Nelson, J.S. Puskin, and A.C.B. Richardson, Oak Ridge National Laboratory, Oak Ridge, TN, for the Office of Radiation and Indoor Air, United States Environmental Protection Agency, Washington, DC, EPA 402-R-99-001 and also see Radionuclide Carcinogenicity Slope Factors: HEAST User's Guide" and "Radionuclide Table" (April 16, 2001). 
United States Environmental Protection Agency (USEPA). 2010. " $\$ 300.430$ Remedial Investigation/Feasibility Study and Selection of Remedy," in Title 40 Code of Federal Regulations (CFR) Part 300-National Oil and Hazardous Substances Pollution Contingency Plan, published in Fed. Regist. 59, 47473, 15 September 1994; e-CFR, National Archives and Records Administration (NARA), Washington, DC.

United States Environmental Protection Agency (USEPA). 2011. "Tritium," Radiation Protection, U.S. Environmental Protection Agency, Washington, DC (URL: http://www.epa.gov/radiation/radionuclides/tritium.html).

United States Nuclear Regulatory Commission (USNRC) (2007), “Appendix B to Part 20-Annual Limits on Intake (ALIs) and Derived Air Concentrations (DACs) of Radionuclides for Occupational Exposure; Effluent Concentrations; Concentrations for Release to Sewerage," in Title 10 of Code of Federal Regulations (CFR): Energy; Part 20-Standards for Protection Against Radiation (10 CFR 20), published in Fed. Regist. 72, 55922, 1 October 2007; e-CFR, National Archives and Records Administration (NARA), Washington, DC.

Williams Production Company, 2006. An Overview of the Williams Fork Geological Model and Supporting Reservoir Engineering Data for 10-acre Density Development. Presentation to the Colorado Oil and Gas Commission, April 24, 2006. Available at the Colorado Oil and Gas Conservation Commission website at http://cogcc.state.co.us/ in Library/Piceance Basin.

Ye, M., C.A. Cooper, J.B. Chapman, D. Gillespie, and Y. Zhang. 2009. A Geologically Based Markov Chain Model for Simulating Tritium Transport With Uncertain Conditions in a Nuclear-Stimulated Natural Gas Reservoir. SPE Reservoir Evaluation \& Engineering, 12(6), 974-984. SPE-114920-PA. doi: 10.2118/114920-PA. 


\section{APPENDIX A: CONVERTING A TRITIUM CONCENTRATION IN PRODUCED WATER $\left(\right.$ HTO $\left._{\text {LIQUID }}\right)$ TO A CORRESPONDING CONCENTRATION OF TRITIUM VAPOR $\left(\mathrm{HTO}_{V}\right)$ AND VICE VERSA}

The concentration of tritium water vapor $\left(\mathrm{HTO}_{v}\right)$ in the flare stack can be approximated from the concentration of tritium in (liquid) produced water $\left(\mathrm{HTO}_{\text {liquid }}\right)$ using Eq. A-1 (which depends on local atmospheric conditions of temperature and relative humidity):

$$
\begin{aligned}
& C_{\mathrm{HTO}_{v}}=C_{\mathrm{HTO}_{\text {liquid }}} \times A H \times\left(\frac{1}{\rho_{\mathrm{H}_{2} \mathrm{O}} \times u \mathrm{CF}}\right) \text {, where } \\
& C_{\mathrm{HTO}_{v}}=\text { Activity concentration of tritiated water vapor }\left(\mathrm{HTO}_{v}\right) \text { in air }\left(\mathrm{pCi} / \mathrm{m}_{\text {air }}^{3}\right) \text {; } \\
& C_{\mathrm{HTO}_{\text {liquid }}}=\text { Activity concentration of tritium in liquid water }\left(\mathrm{pCi} / \mathrm{L}_{\mathrm{H}_{2} \mathrm{O}}\right) \text {; } \\
& \mathrm{AH}^{* *}=\text { Absolute humidity of air }\left[\left(\mathrm{g}_{\mathrm{H}_{2} \mathrm{O}} / m^{3} \text { air }\right)_{\mathrm{H}_{2} \mathrm{O}_{v} @ T T^{\circ} \mathrm{C} ; \mathrm{RH} \%}\right] \text {, with respect to a given } \\
& \text { temperature }\left(\mathrm{T}^{\circ} \mathrm{C}\right) \text { and relative humidity }(\mathrm{RH} \%) \text {. } \\
& \rho_{\mathrm{H}_{2} \mathrm{O}}=\text { Density of water }\left[\left(\mathrm{g}_{\mathrm{H}_{2} \mathrm{O}} / \mathrm{cm}^{3}{ }_{\mathrm{H}_{2} \mathrm{O}}\right)_{\mathrm{H}_{2} \mathrm{O} @ T T^{\circ} \text {; Salinity mg/L }}\right] \text {, and representing the } \\
& \text { mass-to-volume conversion factor with respect to a given temperature }\left(\mathrm{T}^{\circ} \mathrm{C}\right) \text { and } \\
& \text { salinity }(\mathrm{mg} / \mathrm{L}) \text {; } \\
& u \mathrm{CF}=\text { Units conversion factor (i.e., } \mathbf{1 0}^{+03} \mathbf{c m}_{\mathrm{H}_{2} \mathrm{O}}^{3} / \mathbf{L}_{\mathrm{H}_{2} \mathrm{O}}= \\
& 10^{+06} \mathbf{c m}_{\mathrm{H}_{2} \mathrm{o}}^{3} / \mathrm{m}_{\mathrm{H}_{2} \mathrm{O}}^{3} \times 10^{-03} \mathrm{~m}_{\mathrm{H}_{2} \mathrm{O}}^{3} / \mathbf{L}_{\mathrm{H}_{2} \boldsymbol{O}} \text { ). }
\end{aligned}
$$

Table A-1 contains the different activity concentrations of tritium water vapor $\left(\mathrm{HTO}_{v}\right)$ based on summer and winter atmospheric conditions (i.e., representative of extremes) of temperature, relative humidity, absolute humidity, and water density near Project Rulison that were converted from a produced water concentration of tritium $\left(\mathrm{HTO}_{\text {liquid }}\right)$ of $400 \mathrm{pCi} / \mathrm{L}$. The liquid concentration of $400 \mathrm{pCi} / \mathrm{L}$ is the minimum detectable concentration required by the USDOE Rulison Monitoring Plan (USDOE, 2010). The maximum $\mathrm{HTO}_{v}$ concentration will be $6.0 \mathrm{pCi} / \mathrm{m}^{3}$ during summer (grayed cell of Table A-1).

It is important to note that the air concentration of $\mathrm{HTO}_{v}$ released into the atmosphere from the top of the flare stack will then be mixed with non-tritiated water vapor in the air as a

\footnotetext{
** For comparison, absolute humidy (AH) was determined for both minimum and maximum temperatures and corresponding percentiles of relative humidities (RHs) in Rifle, CO (see URL: http://www.city-data.com/city/RifleColorado.html), which is near Project Rulison. These AH values occur in winter and summer and range from $5.4 \mathrm{~g} / \mathrm{m}^{3}$ (at $5{ }^{\circ} \mathrm{C}$ and $80 \% \mathrm{RH}$, during winter) to $15.2 \mathrm{~g} / \mathrm{m}^{3}$ (at $30{ }^{\circ} \mathrm{C}$ and $50 \% \mathrm{RH}$, during summer). The $\mathrm{AH}$ values were computed from temperature and humidity using approximations in the "Climate/Humidity Table" available from Transportation Information Service (TIS) of German Marine Insurers [` Gesamtverband der Deutschen Versicherungswirtschaft e.V. (GDV), Berlin, Germany] and available January 2011 at URL: http://www.tisgdv.de/tis_e/misc/klima.htm].
} 
result of wind, buoyancy differences (especially for temperature differences during flaring), and diffusion. These processes are dispersive and effectively and rapidly reduce concentrations away from the stack by many orders of magnitude. For example, air concentrations of tritium activity reported by Anspaugh et al. (1971) that were collected at eight sample locations within a few hundred feet of the flare on the morning of October 29, 1970, averaged about $140 \mathrm{pCi} / \mathrm{m}^{3}$ (range: 110 to $180 \mathrm{pCi} / \mathrm{m}^{3}$ ); whereas, the concentration calculated to be at the top of the flare stack for this date and time is estimated to be about $2 \times 10^{8} \mathrm{pCi} / \mathrm{m}^{3}$ [based on the quotient of a source term release rate of $1.9 \times 10^{9} \mathrm{pCi}\left(\mathrm{H}^{3}\right) / \mathrm{sec}$ cited by Anspaugh et al. (1971) and a flow rate for that time reported by Smith (1971) of $\left.1.4 \times 10^{7} \mathrm{ft}^{3} / \mathrm{d}\left(4.5 \mathrm{~m}^{3} / \mathrm{sec}\right)\right]$. Empirically, this equates to a dilution factor within a few hundred feet of the stack of more than $1 \times 10^{6}$.

Table A-1. Concentrations of tritium vapor $\left(\mathrm{HTO}_{v}\right)$ in $\mathrm{pCi} / \mathrm{m}^{3}$ for summer and winter atmospheric conditions of temperature, relative humidity, absolute humidity, and water density near Project Rulison, converted from a tritium concentration in produced water $\left(\mathrm{HTO}_{\text {liquid }}\right)$ equal to $400 \mathrm{pCi} / \mathrm{L}$.

\begin{tabular}{l|cc}
\hline Atmospheric conditions & Summer $^{\mathbf{a}}$ & Winter $^{\mathbf{a}}$ \\
\hline Temperature $\left(\mathrm{T}={ }^{\circ} \mathrm{C}\right)$ & 30 & 5.0 \\
\hline Relative humidity ${ }^{\mathbf{a}}(\mathrm{RH}=\%)$ & 50 & 80 \\
\hline Absolute humidity $\left(\mathrm{AH}=\mathrm{g} / \mathrm{m}^{3}\right)$ & 15.2 & 5.4 \\
\hline Water density $^{\mathbf{b}}\left(\rho_{\mathrm{H}_{2} \mathrm{O}}=\mathrm{g} / \mathrm{cm}^{3}\right)$ & 1.008 & \\
\hline $\mathrm{HTO}_{v}\left(\mathrm{pCi} / \mathrm{m}^{3}\right)$ equating to a $\mathrm{HTO}_{\text {liquid }}$ of & & 2.013 \\
$400 \mathrm{pCi} / \mathrm{L}$ & $\mathbf{6 . 0}$ & \\
\hline
\end{tabular}

${ }^{a}$ Summer and winter atmospheric conditions available for Rifle, CO (see "Average Climate in Rifle, CO," available December 2010 at URL: http://www.city-data.com/city/Rifle-Colorado.html), the city nearest to Project Rulison for which data are available.

${ }^{\text {b}}$ The density of water $\left({ }^{\rho} \mathrm{H}_{2} \mathrm{O}\right)$ at $5{ }^{\circ} \mathrm{C}$ and $30^{\circ} \mathrm{C}$ was determined using the "Water Density Calculator" created with the assistance of the University of Michigan and the National Oceanic and Atmospheric Administration (NOAA) and available from the Computer Support Group Network (at URL:

http://www.csgnetwork.com/h2odenscalc.html). The calculation is made with respect to a representative formation-water salinity equal to $16,236 \mathrm{mg} / \mathrm{L}$ (which is consistent with the salinity for groundwater in the Mesaverde aquifer of the Piceance Basin in Colorado that is reported by USGS to exceed 10,000 mg/L; see "Ground-Water Quality" in Mesa Verde Aquifer section of USGS Groundwater Atlas of the United States for Arizona, Colorado, New Mexico, and Utah, HA 730-C available December 2010 at URL: http://pubs.usgs.gov/ha/ha730/ch_c/C-text8.html).

Conversely, by rearranging terms of Eq. A-1 into Eq. A-2,

$C_{\mathrm{HTO}_{\text {liquid }}}=C_{\mathrm{HTO}_{v}} \times \rho_{\mathrm{H}_{2} \mathrm{O}} \times\left(\frac{1}{\mathrm{AH}} \times u \mathrm{CF}\right)$,

the concentration of $\mathrm{HTO}_{\text {liquid }}$ can be determined from a concentration of $\mathrm{HTO}_{v}$. 
Table A-2 contains a comparison of tritium concentrations in produced water corresponding to summer and winter atmospheric conditions and associated with different concentrations of atmospheric $\mathrm{HTO}_{v}$. The values for $\mathrm{HTO}_{v}$ were derived using Eq. (1) from the main text and the parameter values described there, and solving for the $\mathrm{HTO}_{v}$ resulting in worker and resident excess cancer morbidity risk of $1 \times 10^{-6}$.

The $\mathrm{HTO}_{\text {liquid }}$ in the last two columns of Table A-2 represent concentrations in product water that could, for a worker or resident exposure scenario, under the described atmospheric conditions and exposure duration of 30 days, yield the $\mathrm{HTO}_{v}$ concentrations in the flare stack that could produce a lifetime excess cancer morbidity risk $\leq 1 \times 10^{-6}$, if inhaled. However, it is important to note that per the exposure scenarios, the $\mathrm{HTO}_{v}$ concentration of concern is that which a person can breathe from the open atmosphere, after dispersing from the flare stack. Therefore, the $\mathrm{HTO}_{v}$ concentration of gas in the flare stack is expected to be on the order of $10^{5}$ to $10^{6}$ more concentrated than at the ground location where it is possibly inhaled. Accordingly, the lowest $\mathrm{HTO}_{\text {liquid }}$ concentration in produced water, neglecting dispersion (shaded cell of Table A-2 in the "Summer" column and equal to $310,000 \mathrm{pCi} / \mathrm{L}$ ), constitutes a monitoring option that would be an exceptionally conservative, health-protective indicator of potential consequences for both workers and residents. 
Table A-2. Comparison of product-water concentrations of tritium $\left(\mathrm{HTO}_{\text {liquid }}\right)$ corresponding to summer and winter atmospheric conditions of temperature, relative humidity, absolute humidity, and water density near Project Rulison, and associated with different concentrations of atmospheric $\mathrm{HTO}_{v}$, which were derived using realistic upper-limit exposure parameters for worker and resident, total lifetime exposure durations of $30 \mathrm{~d}$ and a de minimis excess cancer morbidity risk equal to $1 \times 10^{-6}$.

\begin{tabular}{|c|c|c|c|}
\hline \multicolumn{2}{|c|}{ Atmospheric conditions } & Summer ${ }^{a}$ & Winter $^{a}$ \\
\hline \multicolumn{2}{|c|}{ Temperature $\left(\mathrm{T}={ }^{\circ} \mathrm{C}\right)$} & 30 & 5.0 \\
\hline \multicolumn{2}{|c|}{ Relative humidity ${ }^{\mathrm{a}}(\mathrm{RH}=\%)$} & 50 & 80 \\
\hline \multicolumn{2}{|c|}{ Absolute humidity $\left(\mathrm{AH}=\mathrm{g} / \mathrm{m}^{3}\right)$} & 15.2 & 5.4 \\
\hline \multicolumn{2}{|c|}{ Water density $^{\mathbf{b}}\left(\rho_{\mathrm{H}_{2} \mathrm{O}}=\mathrm{g} / \mathrm{cm}^{3}\right)$} & 1.008 & 1.013 \\
\hline $\begin{array}{l}\text { Exposed } \\
\text { individual }\end{array}$ & $\begin{array}{c}\text { Concentration of } \mathrm{HTO}_{v} \\
\text { corresponding to a } \\
\text { de minimis } 1 \times 10^{-6} \text { lifetime } \\
\text { excess morbidity cancer risk } \\
\left(\mathrm{pCi} / \mathrm{m}^{3}\right)\end{array}$ & $\begin{array}{c}\text { Produced water } \\
\text { concentration of } \mathrm{HTO}_{\text {liquid }} \\
(\mathrm{pCi} / \mathrm{L})\end{array}$ & $\begin{array}{c}\text { Produced water } \\
\text { concentration of } \mathrm{HTO}_{\text {liquid }} \\
(\mathrm{pCi} / \mathrm{L})\end{array}$ \\
\hline Worker & $9.9 \times 10^{+03}$ & $6.6 \times 10^{+05}$ & $1.9 \times 10^{+06}$ \\
\hline Resident adult & $1.5 \times 10^{+04}$ & $9.8 \times 10^{+05}$ & $2.8 \times 10^{+06}$ \\
\hline Resident child & $4.6 \times 10^{+03}$ & $3.1 \times 10^{+05}$ & $8.6 \times 10^{+05}$ \\
\hline
\end{tabular}

a Summer and winter atmospheric conditions available for Rifle, CO (see "Average Climate in Rifle, CO," available December 2010 at URL: http://www.city-data.com/city/Rifle-Colorado.html), the city nearest to the Project Rulison for which data are available.

b The density of water $\left({ }^{\rho_{2} \mathrm{O}}\right)$ at $5{ }^{\circ} \mathrm{C}$ and $30^{\circ} \mathrm{C}$ was determined using the "Water Density Calculator" created with the assistance of the University of Michigan and the National Oceanic and Atmospheric Administration (NOAA) and available from the Computer Support Group Network (at URL: http://www.csgnetwork.com/h2odenscalc.html). The calculation is made with respect to a representative formation-water salinity equal to $16,236 \mathrm{mg} / \mathrm{L}$ (which is consistent with the salinity for groundwater in the Mesaverde aquifer of the Piceance Basin in Colorado that is reported by USGS to exceed 10,000 mg/L; see "Ground-Water Quality" in Mesa Verde Aquifer section of USGS Groundwater Atlas of the United States for Arizona, Colorado, New Mexico, and Utah, HA 730-C available December 2010 at URL: http://pubs.usgs.gov/ha/ha730/ch_c/C-text8.html). 


\section{APPENDIX A REFERENCES}

Anspaugh, L.R., J.J. Koranda, and W.L. Robison, 1971, Environmental Aspects of Natural Gas Stimulation Experiments with Nuclear Devices. In Nelson, D.J. (ed.), National

Symposium on Radioecology, Oak Ridge, Tennessee, CONF-710501--P1, pp. 37-52.

Smith, G.F., 1971. Gas Analysis Results for Project Rulison Production Testing Samples, Lawrence Livermore National Laboratory, Livermore, CA UCRL-51153.

United States Department of Energy (USDOE). 2010. Rulison Monitoring Plan., U.S. Department of Energy, Office of Legacy Management, Grand Junction, CO, LMS/RUL/S06178. 


\section{APPENDIX B: DERIVATION OF AGE-SPECIFIC HEALTH RISK}

The morbidity cancer risk for adult workers and adult residents was computed using a central estimate of the age-averaged lifetime excess cancer morbidity risk coefficient for inhalation of tritiated water vapor $\left(\mathrm{HTO}_{v}\right)$ that is described in Federal Guidance Report No. 13 and expressed in the "HEAST Radionuclide Table" as equal to $5.62 \times 10^{-14}$ Risk per pCi of $\mathrm{HTO}_{v}$ activity inhaled (see Eq. 1 and Table 2 in text). Because risks from childhood exposure are of special interest, and are likely to be larger than for adults, the age-specific maximum lifetime excess cancer morbidity risk for exposure by a child resident to $\mathrm{HTO}_{v}$ is derived for comparison to the ones for adults. For this to be done both an age-specific risk coefficient expressed per unit of activity and an age-specific breathing rate are needed. Then, these factors can be inserted into Eq. 1 of the text, along with an exposure concentration $\mathrm{HTO}_{v}$ and exposure duration of 30 days, and the result will be an age-specific risk for children from 0 up to $20 \mathrm{y}$ of age.

Columns 1 through 8 of Table B-1 contain the age-specific categories of information that are necessary for determining age-specific morbidity health risk from 0 to $70 \mathrm{y}$ of life, and particularly for the child (from 3 months up to $20 \mathrm{y}$ ). These data correspond to recommended age-specific breathing rates $\left(\mathrm{m}^{3} / \mathrm{d}\right)$, an exposure duration of $30 \mathrm{~d}$, a dimensionless dermal absorption factor of 2, age-specific risk per unit dose coefficients for tritium inhalation exposure ( $\mathrm{R} / \mathrm{Gy}=\mathrm{R} / \mathrm{Sv}$, because tritium dose is considered delivered uniformly), and age-specific dose coefficients for tritium expressed as dose per unit activity $(\mathrm{Sv} / \mathrm{Bq})$, which are then converted to $\mathrm{Sv} / \mathrm{pCi}$ using the conversion factor of $0.037 \mathrm{~Bq}$ per $\mathrm{pCi}$. The product of the age-specific coefficients of risk per unit dose (in units of $\mathrm{R} / \mathrm{Sv}$ ) and dose per unit activity (in units of $\mathrm{Sv} / \mathrm{pCi}$ ) yields the derived age-specific morbidity risk for inhalation of tritium vapor $\left(\mathrm{HTO}_{v} ; \mathrm{R} / \mathrm{pCi}\right)$. These derived age-specific morbidity risk coefficients can then be used in Eq. 1 in the text to estimate age-specific morbidity risk from corresponding age-specific breathing rates $\left(\mathrm{m}^{3} / \mathrm{d}\right)$, days of exposure $(30 \mathrm{~d})$, and applicable air concentrations $\left(\mathrm{pCi} / \mathrm{m}^{3}\right)$. Columns 9 through 12 contain the air concentration assumptions and present the age-specific risk calculations that result from such assumed exposures. Note that the risk for a child from 0 up to 20 years of age is maximum for exposure at 1-y of age (see row in gray), and that this maximum is greater than for an adult (from 20 to 70 -y of age). Also, note that the average risk calculated for adults aged 20 to $70 \mathrm{y}$ in Table B-1 approximates that in Table 2 of the text, calculated using the age-averaged risk coefficient from the HEAST table (the average derived inhalation morbidity risk coefficient for the adult is $5.7 \times 10^{-14} \mathrm{R} / \mathrm{pCi}$ from Table B-1, in comparison to $5.62 \times 10^{-14} \mathrm{R} / \mathrm{pCi}$ from Table 2 in the text).

The uncertainty in the dose coefficient is controversial, and may range from 1 to 10 (CERRIE, 2004). However, a review by Harrison et al. (2002) concludes that the central values for dose-coefficients for adults are known to be within a factor of 2 of the International Commission on Radiological Protection (ICRP) values for inhalation, and though the uncertainty in dose coefficients for children are likely to be greater than for adults because fewer data exist, at this time they may also be taken to be about twice the value of the ICRP dose coefficients, which represent central values. 
Table B-1. Derivation of age-specific (0 to 70 y) tritium inhalation morbidity risk coefficients per unit activity (R/pCi) and determination of age-specific maximum lifetime excess cancer morbidity risk for risk and consequence assessment scenarios (see 1-y old R/lifetime). Child is from 3-mo. up to $20 \mathrm{y}$, and adult is considered age 20 to $70 \mathrm{y}$.

\begin{tabular}{|c|c|c|c|c|c|c|c|c|c|c|c|}
\hline $\begin{array}{c}\text { Age } \\
(\mathrm{y})\end{array}$ & $\begin{array}{l}\text { Breathing } \\
\text { Rate } \\
\left(\mathrm{m}^{3} / \mathrm{d}\right)^{\mathrm{a}}\end{array}$ & $\begin{array}{c}\text { Exposure } \\
\text { duration } \\
\text { (d/lifetime) }\end{array}$ & $\begin{array}{c}\text { Dermal } \\
\text { absorp- } \\
\text { tion } \\
\text { factor }\end{array}$ & $\begin{array}{c}\text { Age- } \\
\text { specific } \\
\text { whole- } \\
\text { body } \\
\text { tritium risk } \\
\text { coefficient } \\
\text { per unit } \\
\text { dose } \\
(\text { Risk/Sv) }\end{array}$ & $\begin{array}{l}\text { Tritiated } \\
\text { water age- } \\
\text { specific } \\
\text { inhalation } \\
\quad \text { dose } \\
\text { coefficient } \\
(\mathrm{Sv} / \mathrm{Bq})^{\mathrm{c}}\end{array}$ & $\begin{array}{c}\text { Tritiated } \\
\text { water } \\
\text { age-specific } \\
\text { inhalation } \\
\text { dose } \\
\text { coefficient } \\
(\mathrm{Sv} / \mathrm{pCi})^{\mathrm{d}}\end{array}$ & $\begin{array}{c}\text { Derived } \\
\text { tritium } \\
\text { inhalation } \\
\text { morbidity } \\
\text { risk } \\
\text { coefficient } \\
\text { per unit } \\
\text { activity } \\
(\mathbf{R} / \mathbf{p C i})^{\mathrm{e}} \\
\end{array}$ & $\begin{array}{l}\text { Tritium vapor } \\
\text { air concentra- } \\
\text { tion equating } \\
\text { to } 400 \mathrm{pCi} / \mathrm{L} \\
\text { maximum } \\
\text { detection } \\
\text { concentration } \\
\text { in produced } \\
\text { water }\left(\mathrm{pCi} / \mathrm{m}^{3}\right)^{\mathrm{f}}\end{array}$ & $\begin{array}{l}\text { Lifetime } \\
\text { excess } \\
\text { cancer } \\
\text { morbidity } \\
\text { risk for } \\
\text { Risk } \\
\text { Assessment } \\
\text { (R/lifetime) }^{\mathrm{g}}\end{array}$ & $\begin{array}{c}\text { Maximum } \\
\text { tritium vapor } \\
\text { air } \\
\text { concentration } \\
\text { at time of } \\
\text { flaring in } 1970 \\
\left(\mathrm{pCi} / \mathrm{m}^{3}\right)^{\mathrm{h}}\end{array}$ & $\begin{array}{c}\text { Lifetime } \\
\text { excess cancer } \\
\text { morbidity } \\
\text { risk for } \\
\text { Consequence } \\
\text { Assessment } \\
\text { (R/lifetime) }\end{array}$ \\
\hline $3 \mathrm{mo}$. & 2.86 & 30 & 2 & $3.97 \times 10^{-1}$ & $6.40 \times 10^{-11}$ & $2.37 \times 10^{-12}$ & $9.40 \times 10^{-13}$ & $6.00 \times 10^{-5}$ & $9.68 \times 10^{-15}$ & $5.60 \times 10^{2}$ & $9.03 \times 10^{-8}$ \\
\hline 1 & 5.16 & 30 & 2 & $3.97 \times 10^{-1}$ & $4.80 \times 10^{-11}$ & $1.78 \times 10^{-12}$ & $7.05 \times 10^{-13}$ & $6.00 \times 10^{-5}$ & $1.31 \times 10^{-14}$ & $5.60 \times 10^{2}$ & $1.22 \times 10^{-7}$ \\
\hline 5 & 8.72 & 30 & 2 & $2.85 \times 10^{-1}$ & $3.10 \times 10^{-11}$ & $1.15 \times 10^{-12}$ & $3.27 \times 10^{-13}$ & $6.00 \times 10^{-5}$ & $1.03 \times 10^{-14}$ & $5.60 \times 10^{2}$ & $9.58 \times 10^{-8}$ \\
\hline 10 & 15.3 & 30 & 2 & $2.23 \times 10^{-1}$ & $2.30 \times 10^{-11}$ & $8.51 \times 10^{-13}$ & $1.90 \times 10^{-13}$ & $6.00 \times 10^{-5}$ & $1.05 \times 10^{-14}$ & $5.60 \times 10^{2}$ & $9.76 \times 10^{-8}$ \\
\hline 15 & 20.1 & 30 & 2 & $1.78 \times 10^{-1}$ & $1.80 \times 10^{-11}$ & $6.66 \times 10^{-13}$ & $1.19 \times 10^{-13}$ & $6.00 \times 10^{-5}$ & $8.58 \times 10^{-15}$ & $5.60 \times 10^{2}$ & $8.01 \times 10^{-8}$ \\
\hline 20 & 22.2 & 30 & 2 & $1.46 \times 10^{-1}$ & $1.80 \times 10^{-11}$ & $6.66 \times 10^{-13}$ & $9.72 \times 10^{-14}$ & $6.00 \times 10^{-5}$ & $7.77 \times 10^{-15}$ & $5.60 \times 10^{2}$ & $7.25 \times 10^{-8}$ \\
\hline 40 & 22.2 & 30 & 2 & $8.70 \times 10^{-2}$ & $1.80 \times 10^{-11}$ & $6.66 \times 10^{-13}$ & $5.79 \times 10^{-14}$ & $6.00 \times 10^{-5}$ & $4.63 \times 10^{-15}$ & $5.60 \times 10^{2}$ & $4.32 \times 10^{-8}$ \\
\hline 50 & 22.2 & 30 & 2 & $7.63 \times 10^{-2}$ & $1.80 \times 10^{-11}$ & $6.66 \times 10^{-13}$ & $5.08 \times 10^{-14}$ & $6.00 \times 10^{-5}$ & $4.06 \times 10^{-15}$ & $5.60 \times 10^{2}$ & $3.79 \times 10^{-8}$ \\
\hline 60 & 22.2 & 30 & 2 & $6.20 \times 10^{-2}$ & $1.80 \times 10^{-11}$ & $6.66 \times 10^{-13}$ & $4.13 \times 10^{-14}$ & $6.00 \times 10^{-5}$ & $3.30 \times 10^{-15}$ & $5.60 \times 10^{2}$ & $3.08 \times 10^{-8}$ \\
\hline 70 & 22.2 & 30 & 2 & $4.30 \times 10^{-2}$ & $1.80 \times 10^{-11}$ & $6.66 \times 10^{-13}$ & $2.86 \times 10^{-14}$ & $6.00 \times 10^{-5}$ & $2.29 \times 10^{-15}$ & $5.60 \times 10^{2}$ & $2.14 \times 10^{-8}$ \\
\hline
\end{tabular}

a Default values for breathing rate are from International Commission on Radiological Protection (ICRP) Publication 71 as cited by Health Canada (1999, Table 1, p. 13).

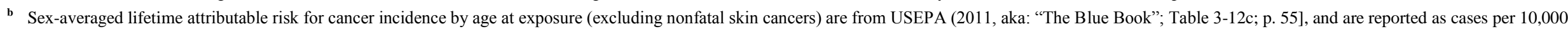
person-Gy, where Gy equates to Sv because tritium is assumed to be delivered uniformly to all tissues, and the coefficient for 0-y is considered applicable from 0 to 5 y of age.

c Age-specific effective dose coefficients for internal exposure to tritiated water taken from ICRP Publication 72 and recommended by Health Canada (1999; Table 2, p. 16).

d Dose coefficient in $\mathrm{Sv} / \mathrm{Bq}$ is converted to $\mathrm{Sv} / \mathrm{pCi}$ by multiplying by the unit conversion factor of $0.037 \mathrm{pCi} / \mathrm{Bq}$.

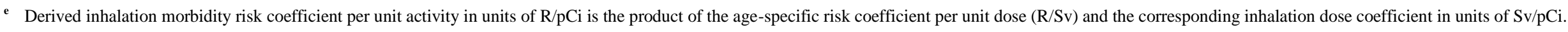

f See Appendix A for derivation of maximum tritium air concentration corresponding to a maximum detectable tritium concentration in produced water of $400 \mathrm{pCi} / \mathrm{L}$.

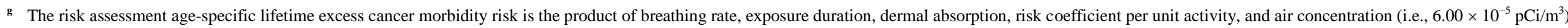
equating to a maximum detectable tritium concentration in produced water of $400 \mathrm{pCi} / \mathrm{L}$.

h The maximum air concentration detected within hundreds of feet of the flare stack during flaring operations performed in 1970 as part of Project Rulison (Anspaugh et al., 1971).

i The consequence assessment age-specific lifetime excess cancer morbidity risk is the product of breathing rate, exposure duration, dermal absorption, risk coefficient per unit activity, and air concentration (i.e., $560 \mathrm{pCi} / \mathrm{m}^{3}$ )equating to the maximum air concentration detected within hundreds of feet of the flare stack during flaring operations performed in 1970 as part of Project Rulison. 


\section{APPENDIX B REFERENCES}

Anspaugh, L.R., J.J. Koranda, and W.L. Robison, 1971, Environmental Aspects of Natural Gas Stimulation Experiments with Nuclear Devices. In Nelson, D.J. (ed.), National Symposium on Radioecology, Oak Ridge, Tennessee, CONF-710501--P1, pp. 37-52.

Committee Examining Radiation Risks of Internal Emitters (CERRIE) (2004), "Report of the Committee Examining Radiation Risks of Internal Emitters (CERRIE)," independent committee established by the government of the United Kingdom, sponsored by Department for the Environment, Food and Rural Affairs, and the Department of Health, London, UK, http://www.cerrie.org/report/ (see Annex 2B: Tritium Doses and Risks).

Harrison, J.D., A. Khursheed, and B.E. Lambert, "Uncertainties in Dose Coefficients for Intakes of Tritiated Water and Organically Bound Forms of Tritium by Members of the Public," Radiat. Prot. Dosimetry 98(3), 229-311.

Health Canada, Joint Working Group of Radiation Protection Bureau (1999), Summary of Recommended Assessment Parameters, Health Canada, Ottawa, Ontario, Canada, http://www.hc-sc.gc.ca/ewh-semt/pubs/radiation/dose/summary-resume-eng.php\#table1 and http://www.hc-sc.gc.ca/ewh-semt/pubs/radiation/dose/index-eng.php.

United States Environmental Protection Agency (USEPA). 2011. EPA Radiogenic Cancer Risk Models and Projections for the U.S. Population, United States Environmental Protection Agency, Washington, DC (April 2011; http://epa.gov/radiation/assessment/bluebook/index.html 